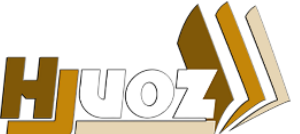

hjuoz.uoz.edu.krd p-ISSN: 2664-4673 e-ISSN: 2664-468
كوّوارا زانستيّن مروّقايهتى يا زانكوّيا زاخوّ

مجلة العلوم الانسانية لجامعة زاخو

Humanities Journal of University of Zakho (HJUOZ)

Vol. 7, No. 3, pp. 309-326, Sept..-2019

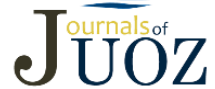

journals.uoz.edu.krd

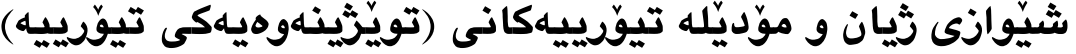

عبدالله خورشيد * و شهلا ولى جبار

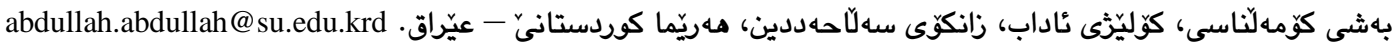
https://doi.org/10.26436/hjuoz.2019.7.3.518 2019/09 بهلاثكرن: وهركرتن: 2019/05 يهـسهندكرن: 2019/07

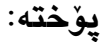

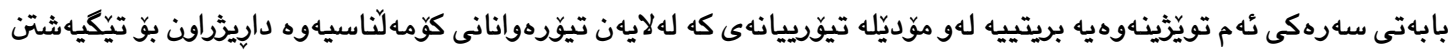

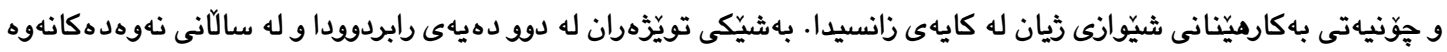

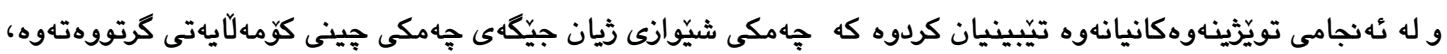
بهلكهى سهرهكيشيان بوّ ئه م مهسه لهيه ئهوهيه كه (جينبهندى ستوونى) كهمتر له شيّوازى زيانى تاكهكان تواناى شروّثهكردنى

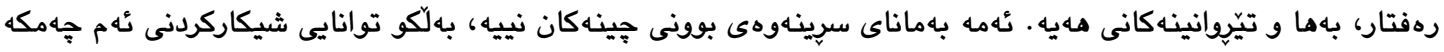

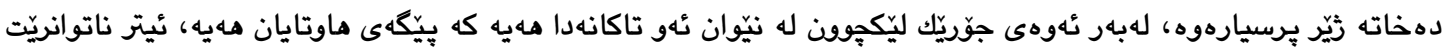

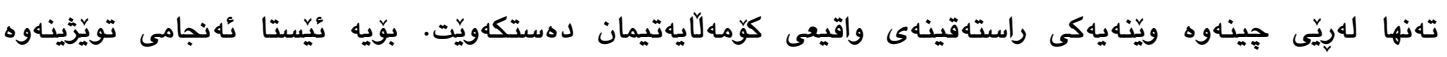

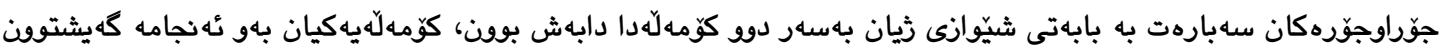

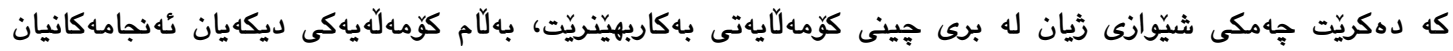

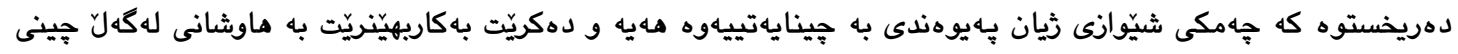

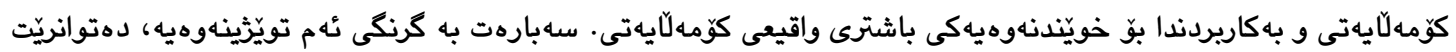

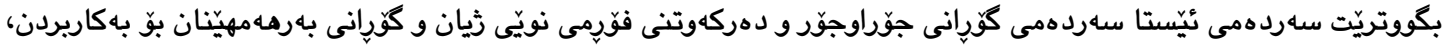

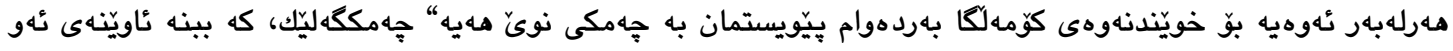

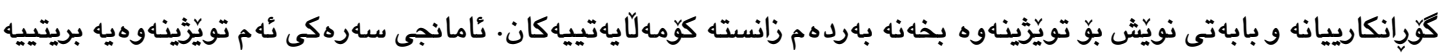

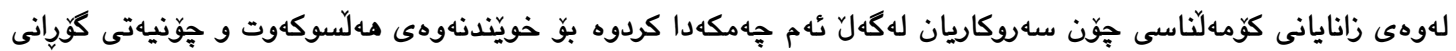

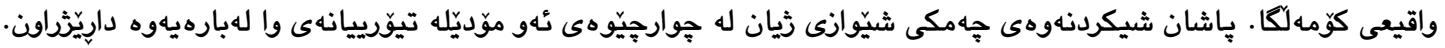

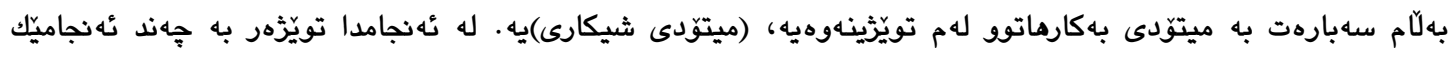

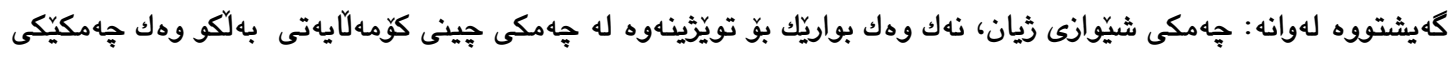

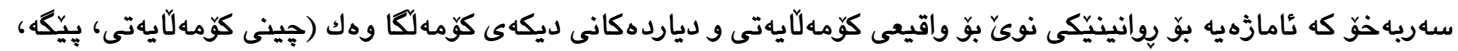

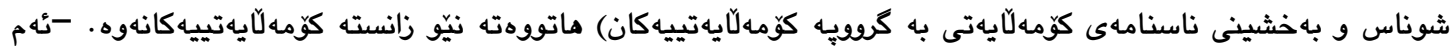

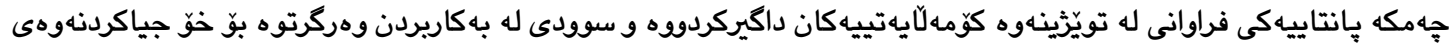

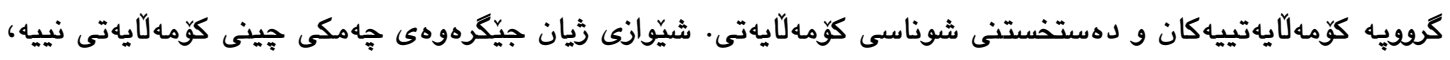

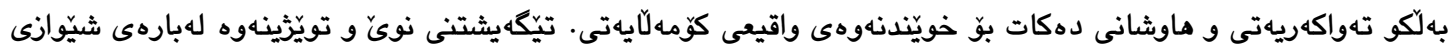

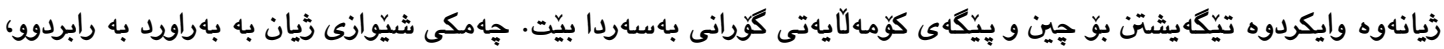

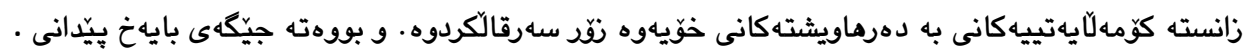

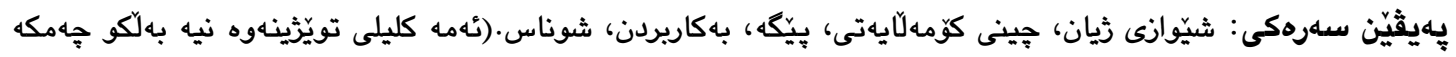
كليليه كانن) له بنيادهكانى ثياندا ثينكهى سروشتى كَّى زهويشيان كَّريوه. بهبى زيادهرهوى بِيِويسته دان بهوهدا بنيّين كه بوّ زانينى ئهوانهى

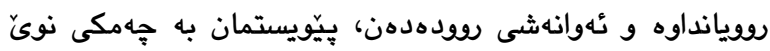

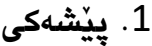

لهدواى جهنگى جيهانيى دووهمهوه، كَّرانكارى خيّرا له هـموو رهههندهانهوه بهسهر جيهاندا هاتوون، بهجوريّك كورِانكارييهكان 


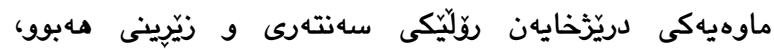
بهتيّيهرِيونى كات كاريكهريى و كارايى لاواز بووه، بهجوَيَّك دوّزينهوهى يه يوهندييهكى تهواو و دلّنياكهرهوه لهنيّوان (خويّندن، كار، داهات و تيّرِوانينى تاك)، سهختتر بووه جههند بهالكَهيهك لهبهر دهستدان ئهوهيان دهرخستووه، كه جيتر بيركردنهوه و رهفتارى

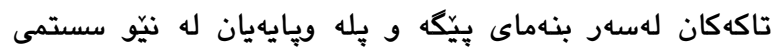

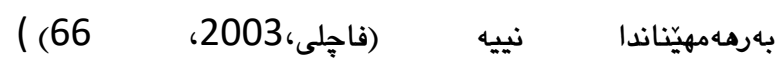
Mohammadpur and Mahmoodi, 2016) (Tomlinson,2003; Pisman, et له تويّزَهرانى ديكه al.,2011; Tolonen,2013) شيّوازى ثيان و فاكتهره جياوازهكانى وهك: بِيّكَى كوّمهلايهتى و

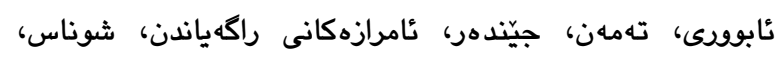
سهرمايهى كولتوورى و متد شيّوثه بكهن. مهدوهما له بِالَ ئهو

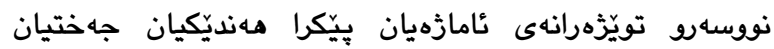

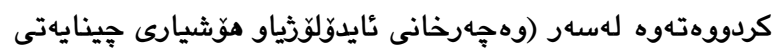

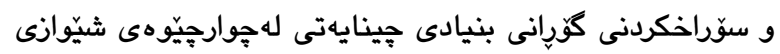

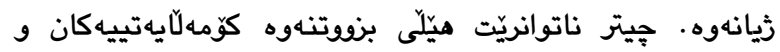
خواستى جينايهتى تاكهكان بههوَى ئينتمايان بو جينيّكى دياريكراو

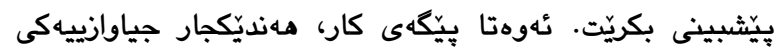

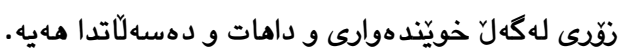
بهسهرنجدان لهو كهشهسهندن و يِيَشكهوتنهى كه كوّمالْاسى ئهميّ بهخوّيهوه بينيوه- بو تيّكهيشتن له بنياد و شوناسى

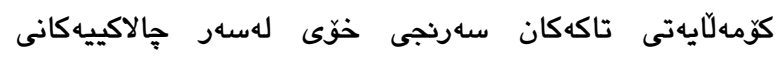
بهرههمهينانهوه كواستوهتهوه بوّ سهر بهكاربردن و خهرجكردن-

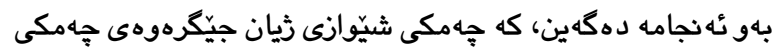
جين نييه، بهلكو هاوشانى جينايهتييه بو شيكردنهوهى واقيعى

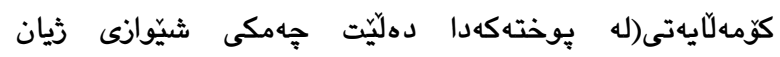

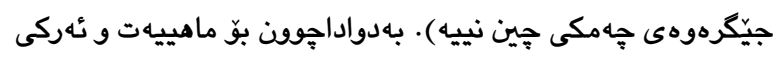

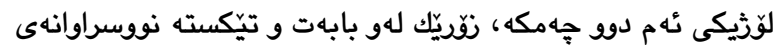

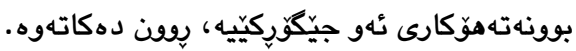
ئه م تويّزينهوهيهى بهردهست بريتيه له تويَزينهوهيهكى تيوّرى و

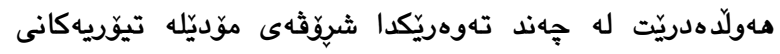
تايبهت به جهمكى شيّوازى ريان بكريّت لهبهر روّثنايى بوّجوونى هزرثانانى بوارى كوّمهلَّاسى. بابهتى سهرهكى ئهم تويَرَينهوهيه

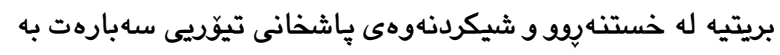

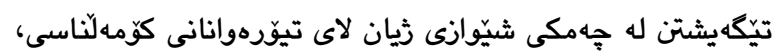
ئهويش لهبهر نئوهى جين له كايه زانستيهكان بهكثتى و لهكايهى

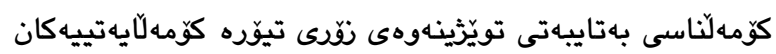

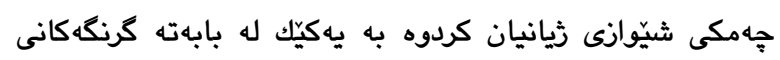

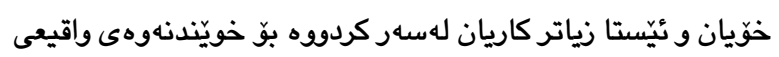

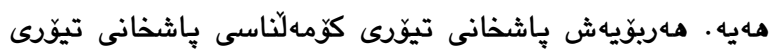
نهك ئهدهبيات)رقّذ بهرّذ جههكى تازهى ديّته ناوهوه، مهموو ئهو

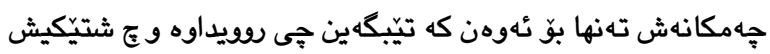

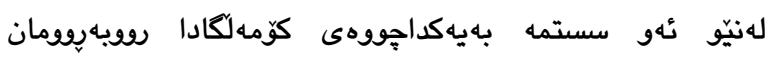
دهبيتهوهـ ههموو شروّثه كوّمهلآيهتييهكان له ريّكَى جهـمكه كشتيه كانهوه به ئهنجام دهكهن و سهرهكيترين تايبهتمهندى لوَزيكى جهمكه كثتيهكانيش، كوكردنهوهى تايبهتمهندييهكانه لهخوّياندا. ئه كهر واتا زقّد و زهوهندهكانى زيانى كوّمهلايهتى لهجوارجيّوهى ئهو جهمكانهدا به شيّوهيهكى ساده دهرنه خريّن و ريّك نهخرينّ، ئهوا ئه گهرى بهدهستهيّنانى هـر جوّره مه عريفهيهكى تيوّريى سستماتيك دهربارهيان و وهرگرتنى ههر حوكميّك لهبارهيانهوه، نهرينى

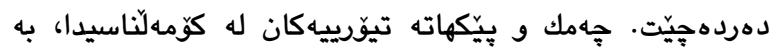
كثتى تايبهتمهندييهكى جهاشن ناسييان هـيه. كيمنزثافت و ويزلشافت (Geminschaft \& Gesellschaft)

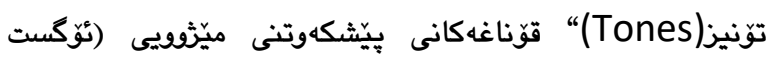

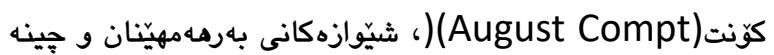

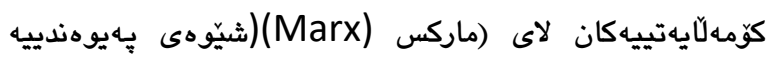

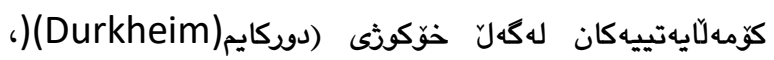

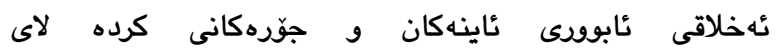

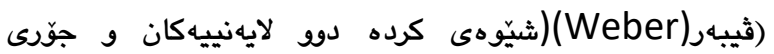

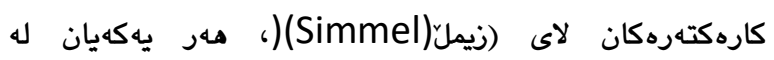

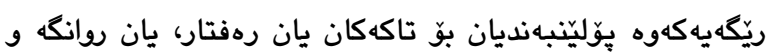

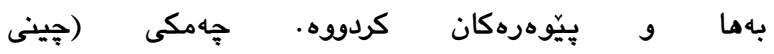
كوّمهلّايهتى)رهكوريشهكهى له نيّو هزرى كوّمهلّايهتى كلاسيك دايه، دواجار مهام دايناميكيبوونى ئهم جهمكه و مهميش جهنديّتى

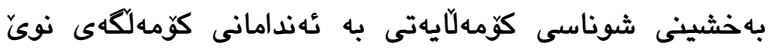
شايانى شروّثه و تيَكَيشتنى تازهيه. ئاراستهى كشتى تيوّره كوّمهلّايه تييهكانى ئهم دهيهى دوايیى بهرهو يـتر بايهذدانه به لايهنى بهكاربردن و جالاكييهكانى شيّوازى ثيان له بهخشينى شوناسى تاكهكهسى و شوناسى كوّمهلآيهتى(اباثرى و جاوشيان، 2002)

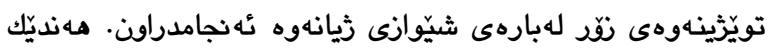

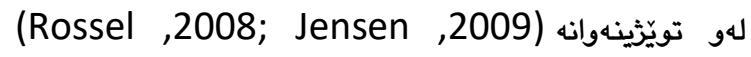
جهختيان كردوهتهوه لهسهر تاوتويّكردنى تيوّريانهى جهمكى

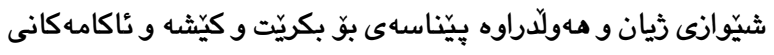
بخرينّهِو. كرنكيدانى زياترى زانسته كوّمهلايهتييهكان به جههمى شيّوازى

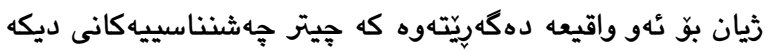
ناتوانن به تهنها ثٔهو فرهيى و مهمه جوريييه كوّمهلاّيهتييانه شروّثه

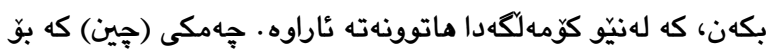


ههنديّك لهو موّديّله تيوّريانهى كه سهرنجيان له بابهتهكه داوه و شوّرثهيان كردوه، دواجار ئاشناكردنى تويَّْران به م بابهته.

\section{2. موّديّله تيورييهكانى شيّوازى ثيان}

كؤمهليّك هوَكار كاريكهرييان هديه لهسهر (شيّوازى ثيان) و ثئهو

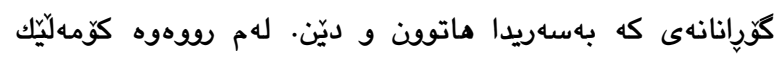

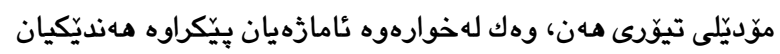
تاييهتن به راستييه نابوودى و كؤمهلآيهتييهكان، ههنديّكى ديكهيان تايبهن به جيهانكيرى و راستى كولتوورييهوه.

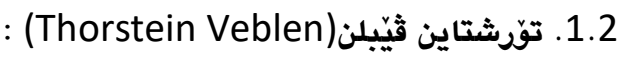

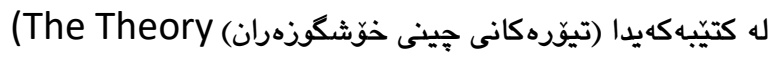
) ( Thorstein تورشتاين ثيّبلن (of Leisure Class) (Veblen) (1857_1929)

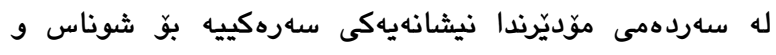

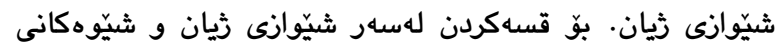
بهاربردن، ئهوا (بِاول ديمكيو) (Paul Dimmgio) بيّيوايه

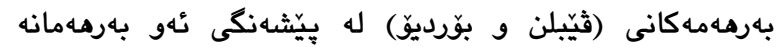

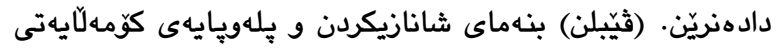

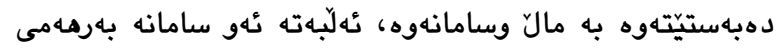

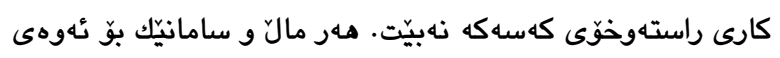
نورترين ريّز و بيّكه بو خاوهنهكهى دهستهبهر بكات، بِيّويسته بهشيّوهى خوّنويّنييانه-بههويهوه خوّى لدهريخات لهبهرامبهر

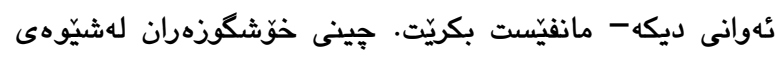
كيانيّ، سهرهتا لهريّكهى بهدهستهيّنانى مالَ و سامانهوه دروستبوو. سامانى زياتر دهسلآتى زياترى بهو جينه بهخشيووه.

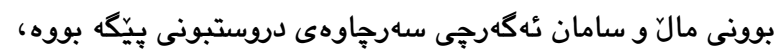

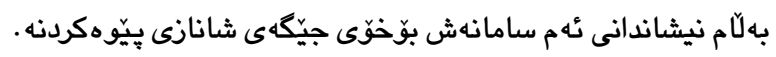

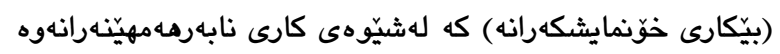
دهردهكويتي، ئهوه نيشاندهرى سامانى تاكهكسهكهيه. كارى

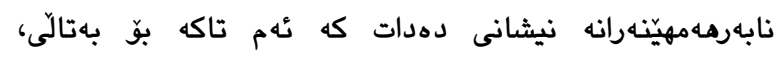

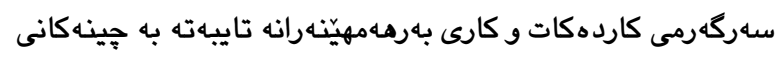

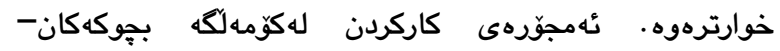
كوندييهكان-كارايى هدبوو، بهلام له كوّمهلكهى شاريدا ئهكهرى

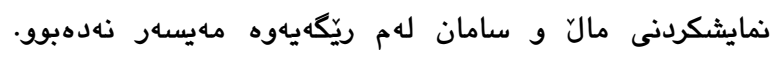
لهكومهلكهى شارنشينيدا (بهكاريردن نمايشكارانه)يه كه خزمهتى

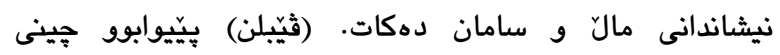
خوّشكوزهران لهو ريّكهيهوه به دهسهلآتيكى سستماتيك دهكهن و و

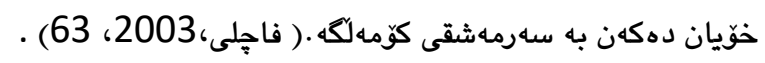

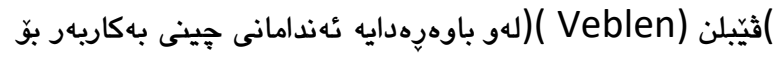

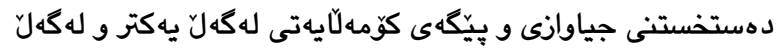

كؤمهلايهتى سهردهمى نويّ، هـروهها هدولَدراوه شيكردنهوه بو هزرى هـريهك له (ثيّبلن)(ماكس ثيبهر) و (جوّرج زيمل) وهك

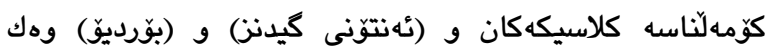

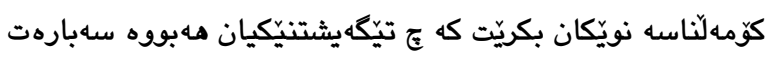
به م بابهته و بوّجى هيّده مشتومريى لهبارهوه ئه نجامدراوه. ئيّستا

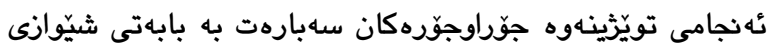

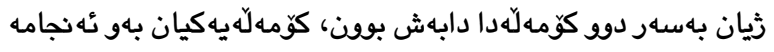

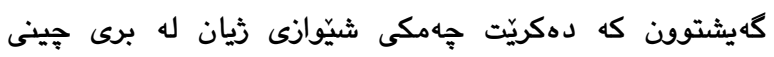

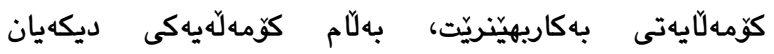

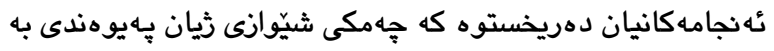

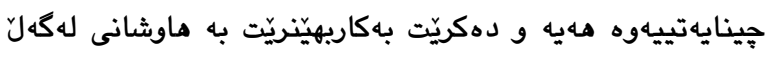

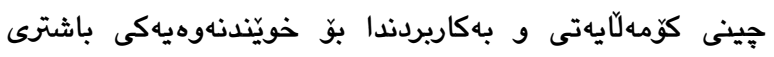
واقيعى كؤمهلآيهتى. سهبارهت به كرنكى ئهم تويَّرينهوهيه، دهتوانريّت بكووتريّت كه كهورهترين كوَّرانكارى له سهردهمى نويّدا

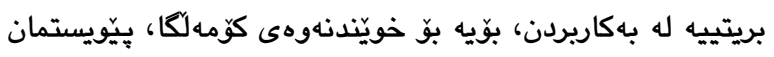

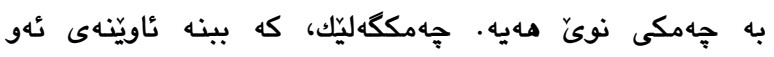
كوّرانكارييانه و بابهتى نويّش بوّ تويَرِينهوه بخهنه بهردهم زانسته كومهلآيهتييهكان. وا دياره كه جهامكى (شيّوازى ريان) ئهو

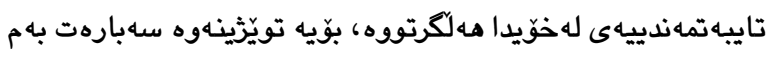

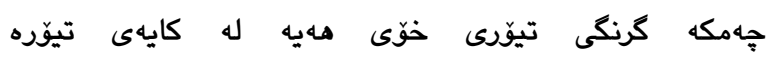

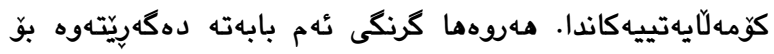

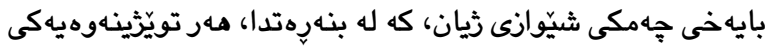

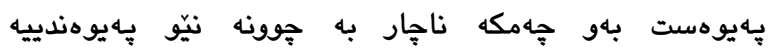

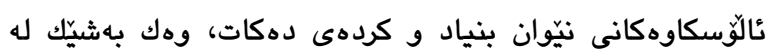

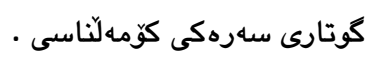
بهلام سهبارهت به ميتودى بهكارهاتوو لهم تويَّرينهوهيه، ئهوا

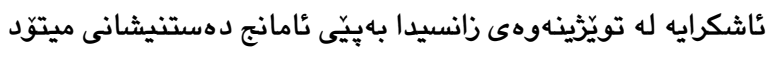

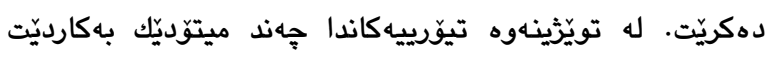

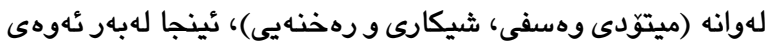
نامانجى ئهم تويَرينهوهيه بريتييه له تيّكهيشتن و شيكردنهاوهى

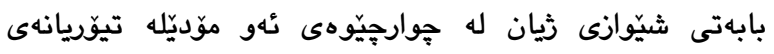

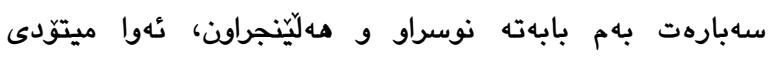
بهكارهاتوو لهم تويَّرينهوهيدا بريتييه له (ميتودى شيكارى)،

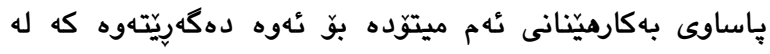

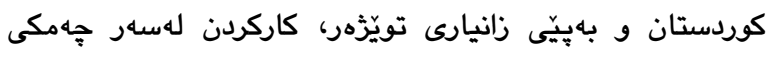

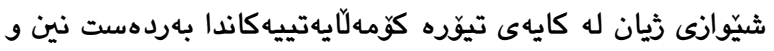

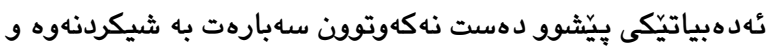

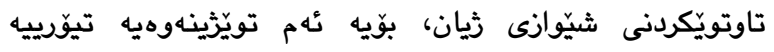

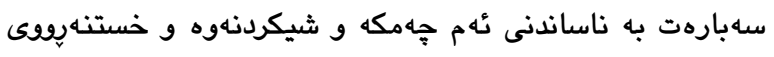


2.2 جوّرج زيملَّ( (Georg Simmel)

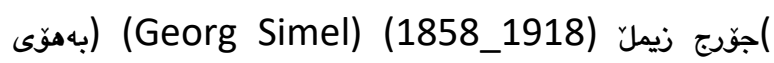

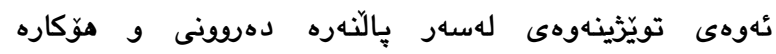
كاريكهرهكان لهسهر دروستبوونى شيّوازهكانى بهكاربردن كردووه،

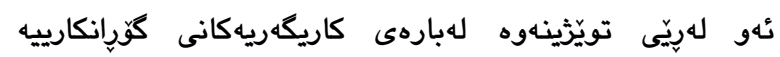

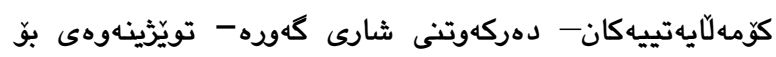

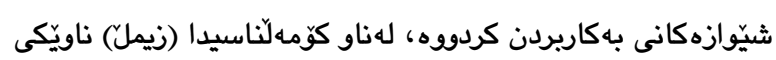

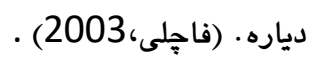

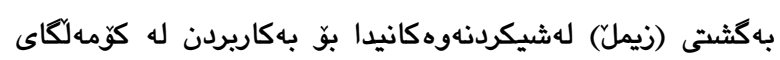
موّديّرندا جهختى لهسهر موّده كردوّتهوه وهك شيِوازيّكى زيانى

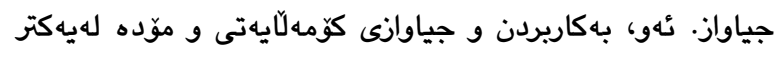
جيادهكاتهوه و يِيّيوايه موّديّرنه و كَّرانكارييهكانى، تاكايهتى و شوناسيّكى نويِيان بوّ تاك ميّناوهته ئاراوه، بهلام ئهم تاكايهتيه

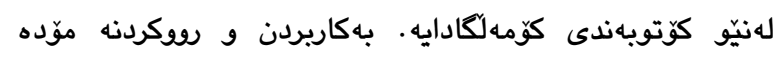

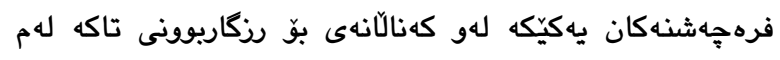
كوّتويهندانه-موّده و بهكاربردن كوّمهليّلك جِالاكى بهدواى خوّياندا دههيّن، لهلايهكهوه شوناسيّكى نوى به تاك دهبه خشن و جيّى

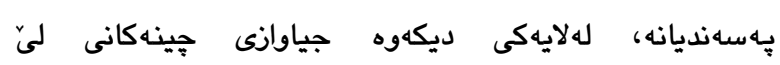
- دهكهويتهوه. (Simmel, 1957) بهمشيّوهيه كروريِّكى خهلّك، كه موّده و بهكاربردنيان ماوشيّوه

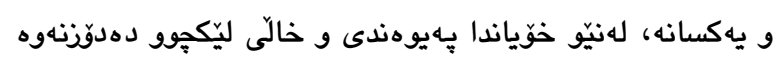
ئهوانى ديكه له ريّكَى موّده و جِوّنيهتى بهكاربردنيان له خوّيانى

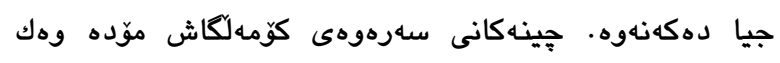

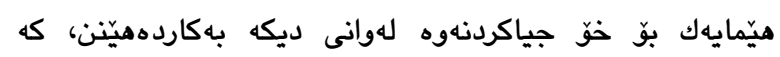

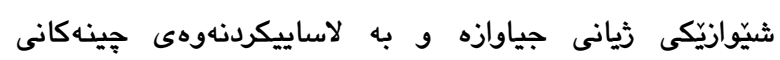

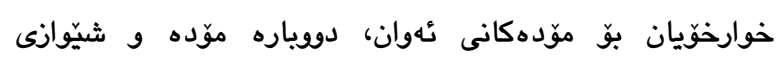
بهكاربردنى نوى ديّنته نَاراوه .

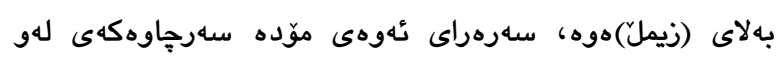
فشارانهوهيه كه جه نجالى نيّو شار دروستى كردووه، ئهوا نيشانهى

(Holt and Searls, 1994). جياوازى نيّوان جينه كانيشه ليّرهدا بوّجوونى (زيمل) سهبارهت به كاريكه ريى دوانهيى موّده

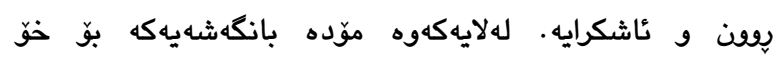
جياكردنهوه لهوانى ديكه و خستنهيويى شوناس و خواستى

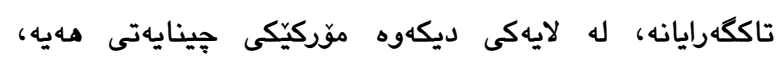

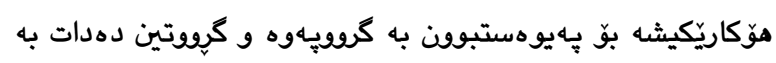

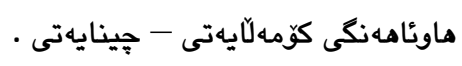

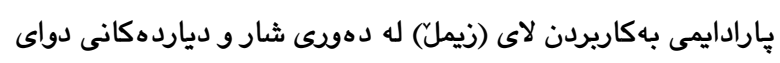

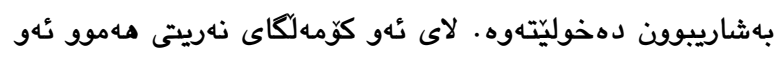

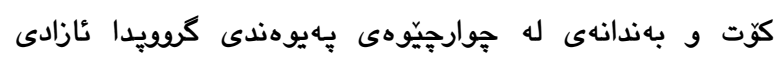
تاكهكهسى بيى تهوق دابوو، مزدهى دهركهوتنى تاكگهرايى دهدا.

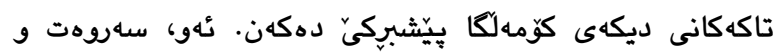

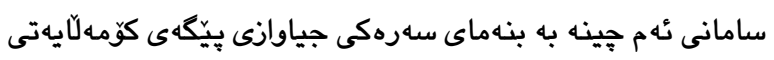

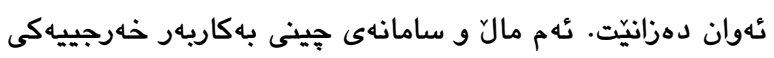

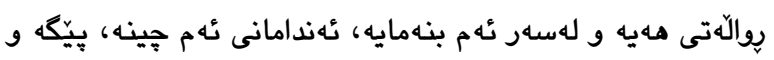

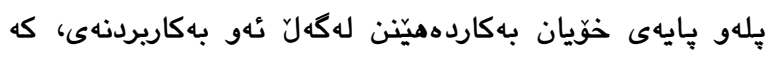
ئه نجامى دهدهن تهنيا بوّ خوّ دهرخستنه، هه مُ خوّيان و جِينه كهيان لهوانى ديكه جيادهكهنهوه، مهميش بوّ خوّيان بههايهكى بهرزتر

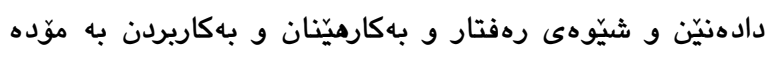

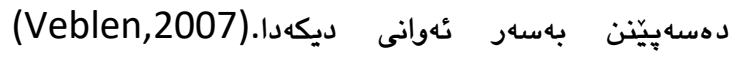

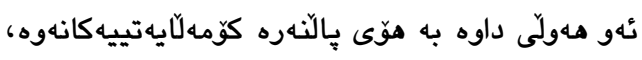
دياردهى موّده شيبكاتهوه" شيكاريهكى رهفتارى ململانيخوازانهى

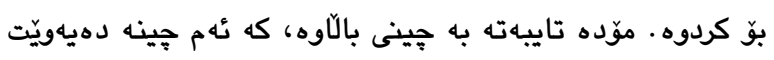
ئهوه نيشان بدات" بوّ بهدهستهينانى دامات ناجِار نييه كار بكات.

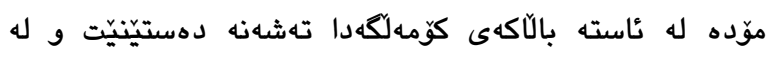
جينهكانى خوارهوهى كوّمهلكهشدا لاسايى دهكريّتهوه مهروها

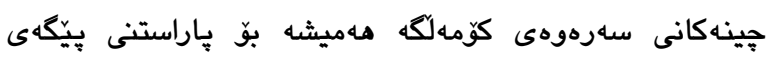
كوّمهلايه تييان شيّوهى نوى له بهكاربردن ديّنته ئاراوه و بهيّوَّانهيى

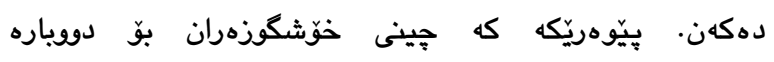

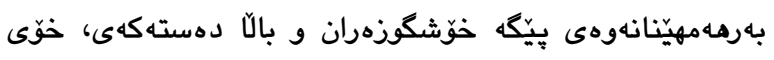

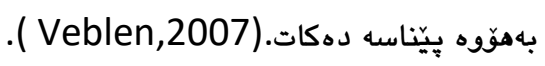

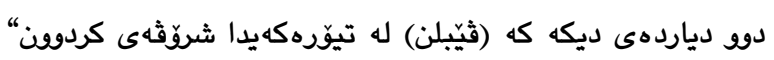
جوانكارى زنان و ههنديّك له رهفتارهكانى ديكهى دهولَّمهندان.

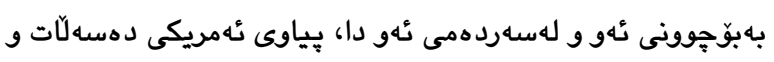

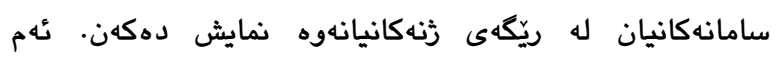

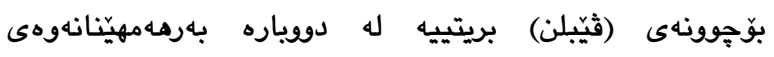

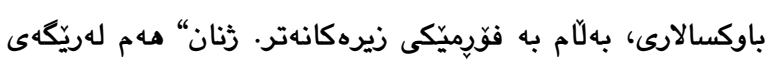

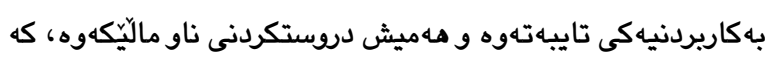

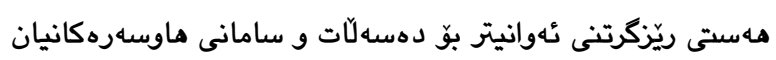

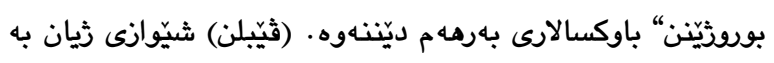

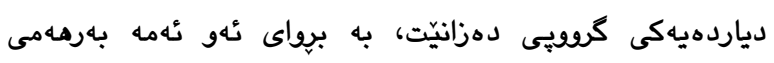
يهيوهستبوونه به جينهكانهوه و ماهيهتيّكى سهربه خوّيانهى نييه

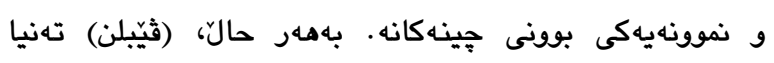
كوّمهلّاسى كلاسيكه كه شيوّثَهى دياردهى بهكاربردنى كردبيّت، مهر بوّيه ش له بابهتى يهيوهست به بهكاربردن و شيّوازى زيانهوه،

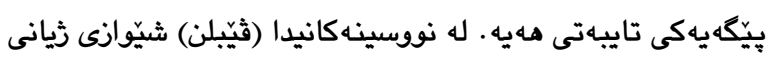
تاكهكه به نموونهيهكى رهفتارى دهستهجهمعى دادهنيّتئهو رهفتارانه له نموونهى ريّورهسم و نهريته كوّمهلاّيهتييهكان و ريّبازه مزرييهكانن- مهروهدا شيّوازى ثيانى تاكهكه به به ئاوينتهيهى رهفتار و ميكانزمى روحى و نهريته هزرى و مه عريفييهكان له قهلّهم

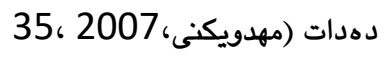


دياره. ميراتى ئهو هيّلّه فكرييهى زيمل دهتوانين لهو كوّمهلّه

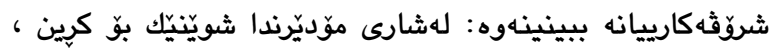

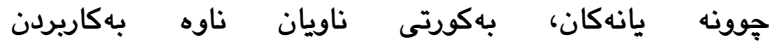
. (فاجلى، (2003، (20) دياردهى بهكاربردن به تهنها و وهك تيّكهيشتنى ثيّبلن لهنيّو

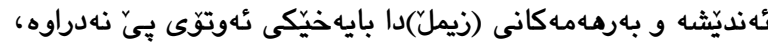
تيوّىى بهكاربردنى زيملّ له دهورى ثار و دياردهكانى دواى بهشاريبوون دهخوليّتهوه. لاى زيمل كومهه لكَهى نهريتى مهموو ئهو

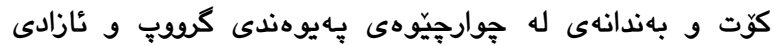
تاكهكهسى يُّ تهوق دابوو، مزدهى دهركهوتنى تاككهرايى دهدا. له شاردا، جوونه ناو سستمى تهون ئاساى دابهشكردنى كار، دروستكردنى شوناس و جيابوونهوه لهوانيترى زيادكردووه ـ له وهما بارودوخيَكدا، شيّوهى تايبهتى بهكاربردن و شيّوازى ثيان،

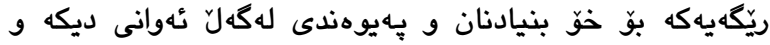
جهنجالّى ناو شار. (زيملّ) دركى بهوه كردبوو كه بوّشثوازييهتى بهرلين بوّ رويهرويونهوه كوماناوييهكهى له نيّو ثيانى شاردا و

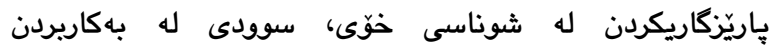

وهردهكرت(Nury, Bezhen and other,2005)

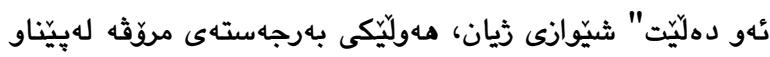

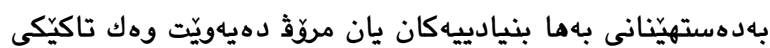
بالَاتر لهنيّو كلتورى باودا خوّى بهوانى ديكه بناسيّنيّت. بهواتايهىى

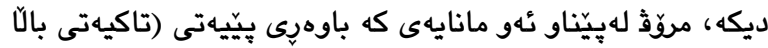

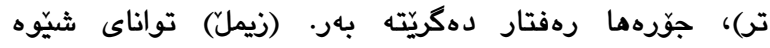
براردهيهكى له جوّرهى ناوناوه (سهليقه) و يههيوهندى نيّوان جّرهكانى سهليقهشى ناوناوه (شيّوانى زيان). هـروها يِيّيوايه شيّوازى زيان بريتييه له بهرجهاتهكردنى هـنديَ بيوياوهرِ" له جوارجيِوهيهكى شيّوه كوَمهلَّايهتييانهدا. جوّره خوّنواندنيّكى وهك

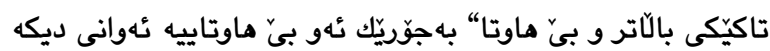
دركى يَّ بكهن سهرهرإى ئهوانهى سهرهوه (زيمل)" ياوازيكردن لهنيّوان شيّوازهكان (رهفتارى يِيّشبينكراو لهجوارجيّوهى كلتورى باودا) و

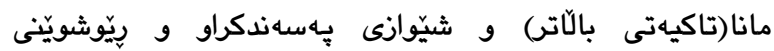
دروستبوونيان، كه مهموويان جوّره شيّوازيّك بن، به ماناوه دهبهستيتهوه. يِيّناسهى (زيمل) ) بوّ شيّوازى ثيان بريتييه له

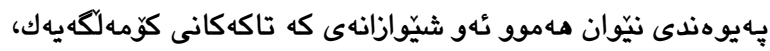

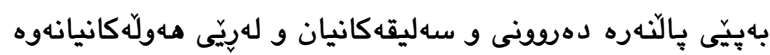
بو هيّنانه كايهى هاوسهنكييهك لهنيّوان كهايهتى ناوهكى و

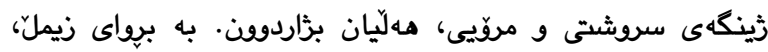

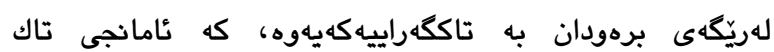

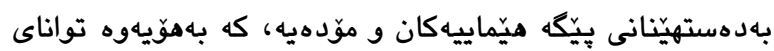

لهشاردا، جوونه ناو سيستهمى تهون ئاساى دابهشكردنى كار، دروستكردنى شوناس و جيابوونهوه لهوانيترى زيادكردووه. له وهها بارودوخيّكدا، شيّوهى تايبهتى به كاربردن و شيّوازى ثيان ريّكَيه كه

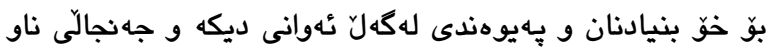
شار) (Simmel,2012)

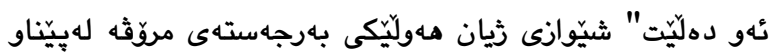
بهدهستهيّنانى بهها بنيادييهكان يان مروّث دهيهويْت وهك تاكيّكى

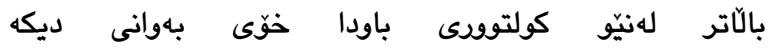

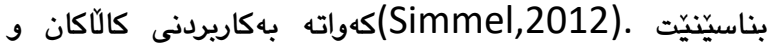
بنيادنانى شيّوازهانى زيان له لايهكهوه شوناسى داوه بهتاك و لهلايهكى ديكهوه جياوازى دروست كردووه بهواتايهكى ديكه، مروّث لهيِيّاو ئهو مانايهى كه باوهيى يِيِيهتى (تاكيهتى بالَّتر) جوّرهها رهفتار ئهنجامدهدات. (زيملّ) تواناى شيّوه براردهيهكى لهم

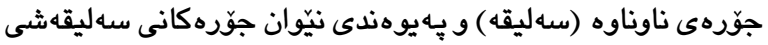
ناوناوه (شيّوانى ثيان). هـروهدا يِيّيوايه شيّوازى ثيان بريتيه له

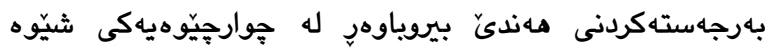

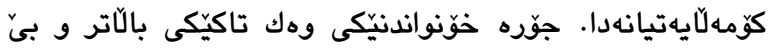

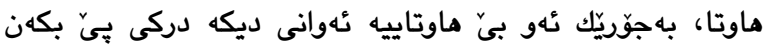
(مهدوى كنى، 2009). سهرهراى ئهوانهى سهرهوه، (زيملّ)، جياوازيكردن لهنيّوان شيّوازهكان (رهفتارى يِيشبينكراو لهجوارجيِيوهى كولتوودى باودا) و ماناى (تاكيهتى بالَاتر) و شيّوازى پِهسهندكراو و رِيَوشويِنى دروستبوونيان، كه ههموويان جههند جوّره شيّوازيّكن، به (مانا)وه دهبهستيتهوه. تيّكهيشتنى (زيملّ) بوّ شيّوازى ريان بريتيه له يه يوهندى نيّوان هـموو ئهو شيّوازانهى كه تاكهكانى كوّمه لكايهك

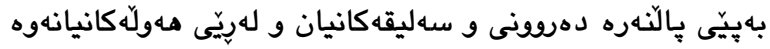
بو هينانه كايهى هاوسهنكيهك لهنيّوان كهايه تى ناوهكى و ثينكهى

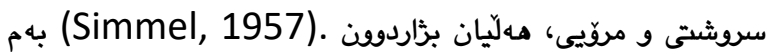

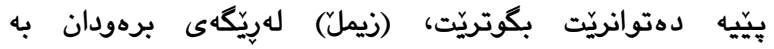

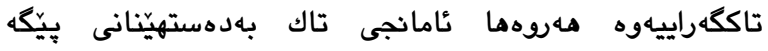
هيّمايهكان و موّدهيه، ئهوا بههويهوه -تاك- تواناى دهبيّت بهركهى

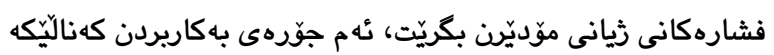

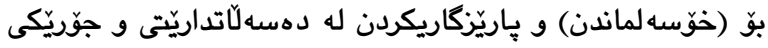

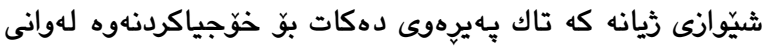
ديكه .

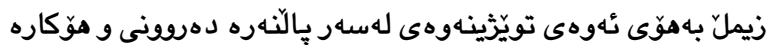
كاريكهرهكان لهسهر دروستبوونى شيّوازهكانى بهكاربردن كردووه و له ريّى تويّزَينهوهى لهبارهى كاريكهرييهكانى كُورِانكارييه

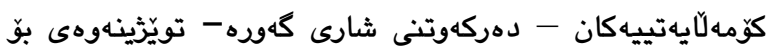

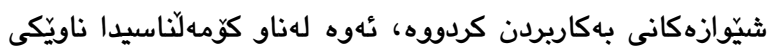


خالّى جياوازيشيان لهو شتانهدايه، كه بهكاريان ديّنن و خهرجيان

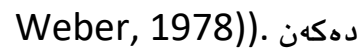

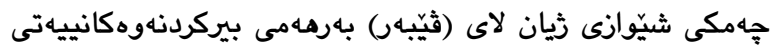

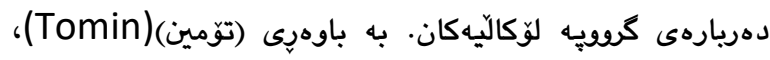

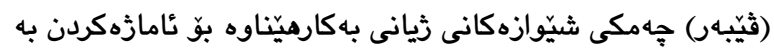
شيّوهانى رِهتار، يُوّشينى جل و بهرگ، قسهكردن، بيركردنهوهو

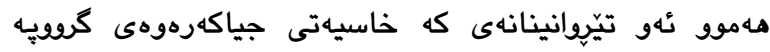
لؤكالّيهان بوون بهلاي ئهو كهسانهوه، كه دهيان ويست به بهشيّاك لهو كروويه لؤكالييه جياوازانه هـرَمار نه كريّن (فاجلى، 2005) .

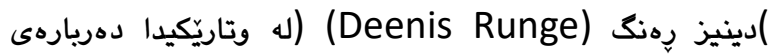
هزرهانى (ثيّبهر) دهليّت: مهبهستى (ثيّبهر) له شيّوازى ثيان،

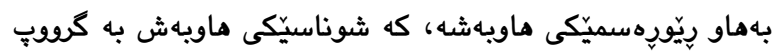

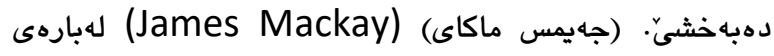
ديدكاى (ثيّبهر) هوه دهليّت: مهبهستى (ثيّبهر) لهشيّوازى ثيان ئهو

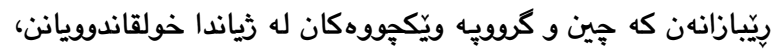
لهبهر ئهوه (ثيّبهر) شيّوازى ثيان به هاوواتاى جِينى كومهالّايهتى

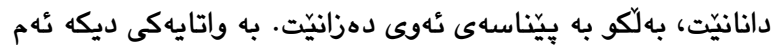
بابهته-شيّوازى زيان- يِيناسهيهكه، كه سنوورى ناديارى نيوان

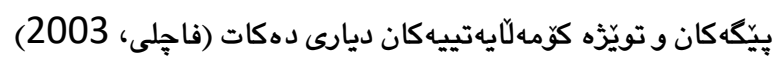

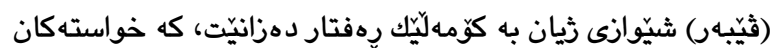

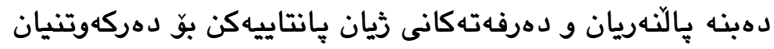

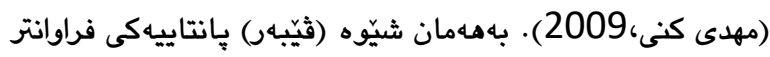

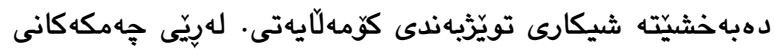

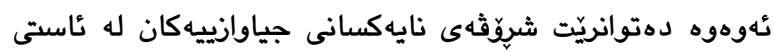
ستونى و ئاسوّييدا بكريّت. بوّ نمونه : جهمكى جِين لاى (ماركس)

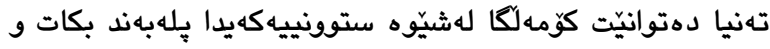
دابهشبونى جينايهتى بو بكات، بهلام جهمكى بِيّكَ دهتوانيّت

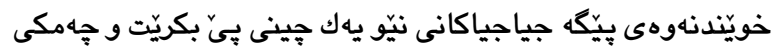

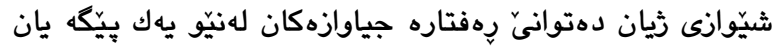
جيندا جيابكاتهوه ـ لهبه ئهوه بهلاى (قيّبهر)هوه شيّوازهكانى ثيان جكه لهوهى جياوازى دروست دهكهن له نيّوان كروبِيهكاندا،

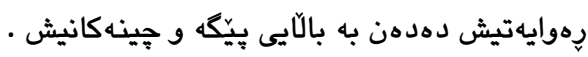
يهكيلك له دهستكهوته كانى ديكهى (ثيّبهر) بريتيه له جهختكردنهوه لهسه كاريكهريى شيّوازهكانى ثيان به ئاراستهى دروستكردنى

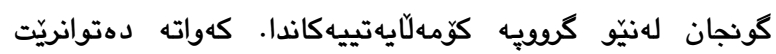

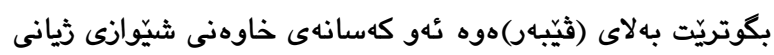

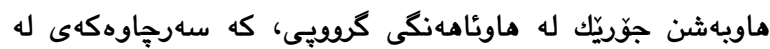

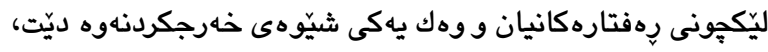

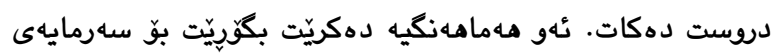

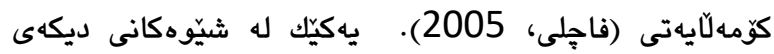

دهبيّت بهركهى فشارهكانى ثيانى موّديّرن بكريّت. ئهم جوَرهى

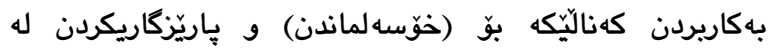

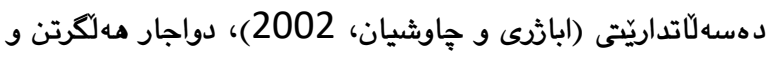
نيشاندانى شيّوازيّكى ثيانى دياريكراو.

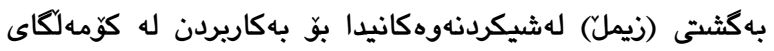
موّديرندا جهختى لهسهر موّده كردوّتهوه وهك شيّوازيّكى ثيانى جياواز. ئهو، بهكاربردن و جياوازى كوّمهلاّيهتى و مؤده لهيه كتر

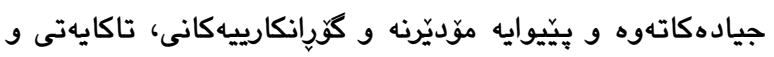
شوناسيّكى نويّيان بو تاك هينّاوهته ئاراوه، بهلام ئهم تاكايهتيه

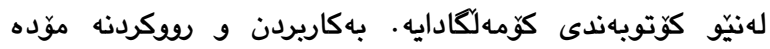

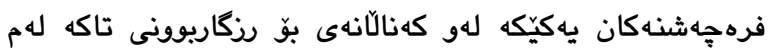
كوّتويهندانه-موّده و بهكاربردن كؤمه لَّلَّك جالاكى بهدواى خوّياندا دهيَّن، لهلايهكهوه شوناسيّكى نوى به تاك دهبهخشن و جيّى

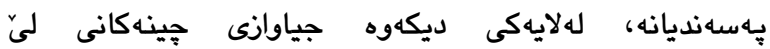
دهكويتّهوه(Nury, Bezhen and ،- (Clemens,2000) other,2005)

3.2. ماكس ثيبهر(Max Weber):

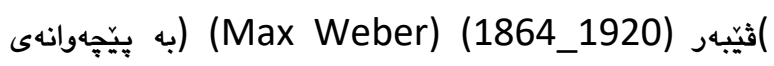
(ثيّبلن و زيمل)، جهمكى شيّوازى زيانى لا مهبهسته. لهناو هـموو

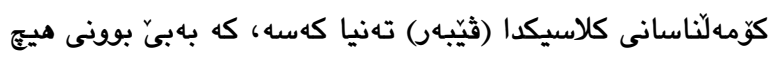

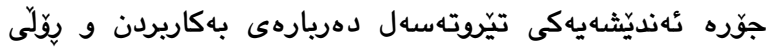

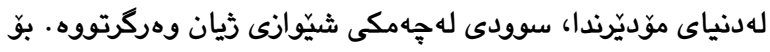

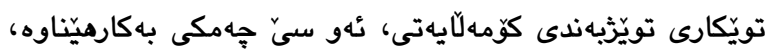

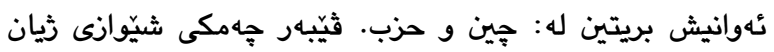

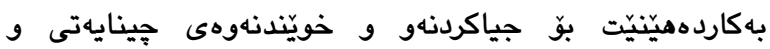

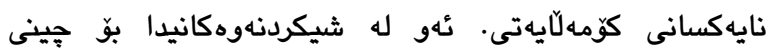

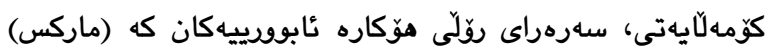

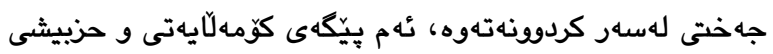

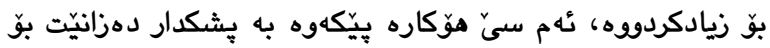

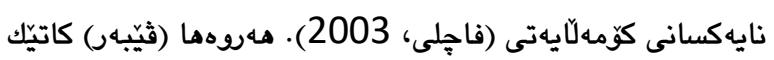

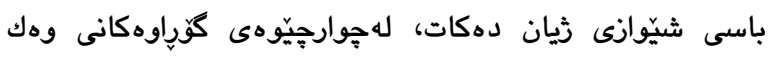
(تهمهن، رهكهز، نهتهوه)وه شيكردنهوهكانى دهات و و بِيّوايه

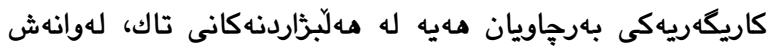

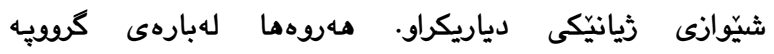

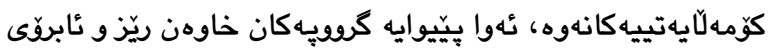
خوّيانن و شيّوانى زيانى تايبهت بهخويان هديه و هدر بهينيّى ئهم

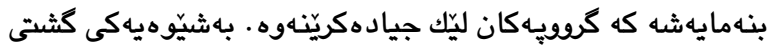

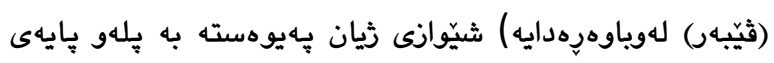

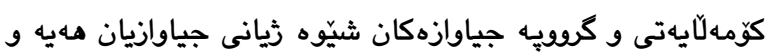




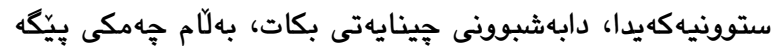

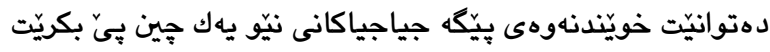

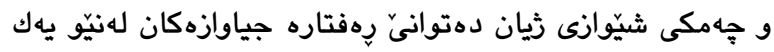

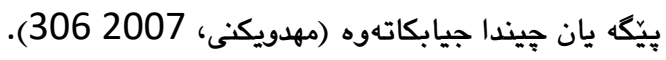

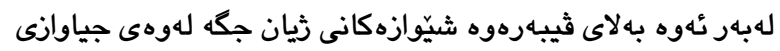
دروست دهكهن لهنيوان گروبيهكان، رهوايهتيش دهدان به بالآيى

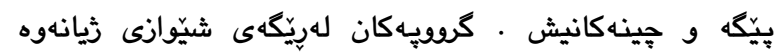

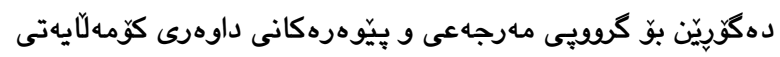

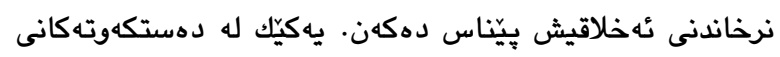
ترى ثيبهر، بريتييه لهجهت كردنهوه لهسهر كاريگهى شيّوازهكانى زيان به ناراستهى دروستكردنى كونجان لهنيّو كرويه جريه كوّمهلاّيهتييهكاندا. بهلایى ثيبهرهوه ئهو كهسانهى خاوهنى شيّوانى زيانى ماويهشن جوّريّك له ماو تُامهنكى كروبيى كه سهرجاوهكهى

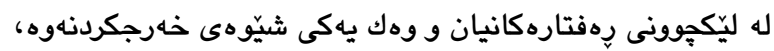
دروست دهكات. ئهو مههامهنكييه دهكريّت بكَوريّت بوّ سهرمايهى

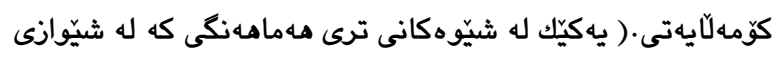
زيانهوه سهرجاوه ده گريّت، بريتييه له كوّرانى بهرهو ورده كلتور.

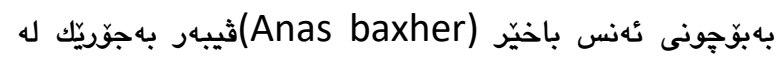
بارهى شيّوانى ثيانهوه دهدويّت وهك بلّيّى باس له وورده كلتور دهكات · (زٔكايى، 2005

(Douglas and Isherwood) د دهاتد م· ج.( برى ن نئاو. 2003

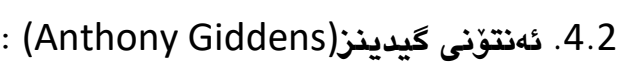
له دهيهكانى رابردوودا تيوّره كوّمهآايهتيهكان جهختيان كردوهتهوه

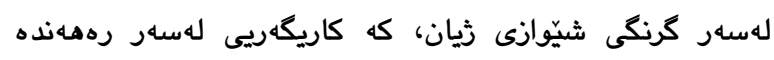
جياوازهكانى ثيانى كوّمهلّايهتى هـيه وهك: شوناسى كوّمهلّايهتى و

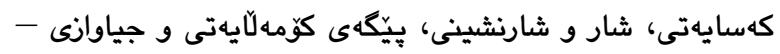
كروييى نايينى و ئيتنى و تهنانهت سياسيش وهك (كيدنز) (1991)

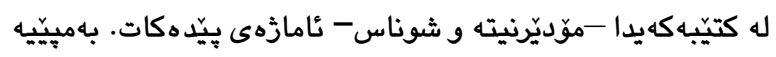
سهرنج دهدريّت كه شيّوازى ريان وهك بابهتيّك بو تيوّريزهى

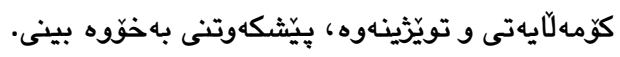

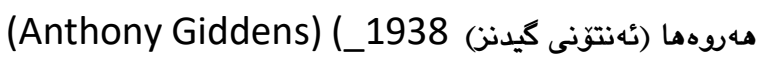
(له هـوليّكى بوّ دهربازيوون له دوفاقى هوّكاريّتى و يِيَكهاتهدا،

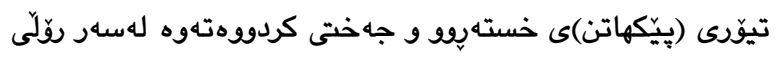
هـردوو فاكتهرهكه له يهك كاتدا و له ديدى ئهوهوه مروّثهان وهك

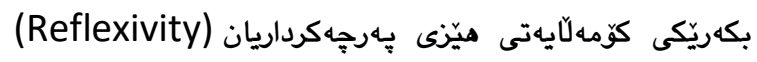

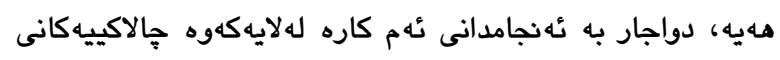

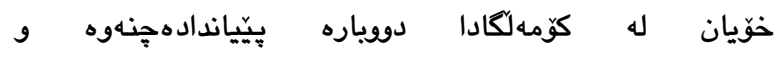
تايبهتمهندييهكانيان دهكوين، لهلايهى ديكهوه بهم كارهيان
هه ماههنكى، كه له شيّوازى ثيانهوه سهرجاوه دهكريّت بريتيه له كوّرانى بهرهو ورده كولتوود. (ثيّبهر) به جوّريّك له بارهى شيّوانى ثيانهوه دهدويّت وهك بلّيّى باس له وورده كولتوود دهكات (مهدى بهى كنى، 2009). لهناو مهموو كوّمهلّاسانى كلاسيكدا ثيبهر تهنها كه كه كه بهبيّ بوونى هيج جوّره ئهنديشهيهكى تيّرتهاسهل دهريارهى بهكاربردن

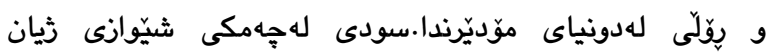

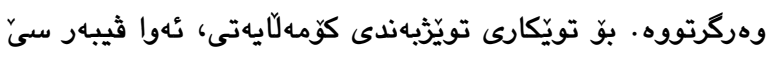
جهمكى بهكارهيناوه ئهوانيش بريتين له جِين ، كرويى لوّكالَى و حزب · ثيبهرو شويّن كهوتوانى دهربارهى بِيَّه دواون (جيلهر)

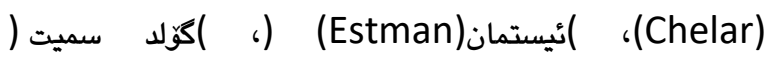

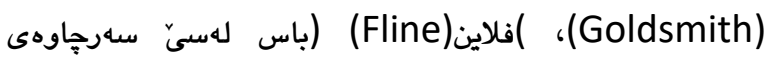

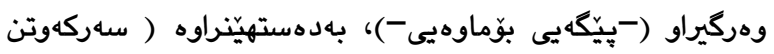

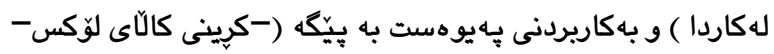

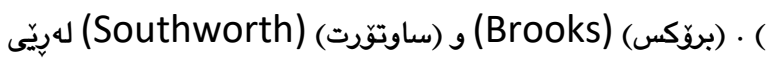
كهرإنهوه بو نوسينهكانى ثيبهر(، مهرسيّ جههمى شيّوازى ثيان

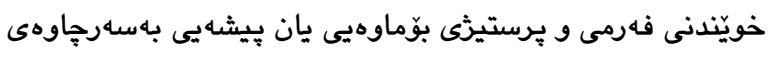

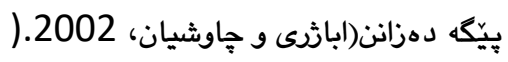
جهمكى شيّوازى ثيان لاى ثيبهر بهرهـمى بيركردنهوهكانيهتى

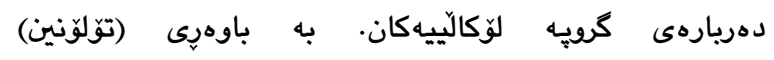
(Tolonen)

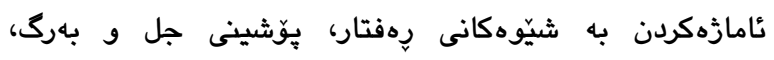

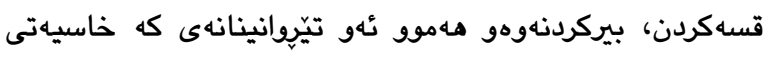

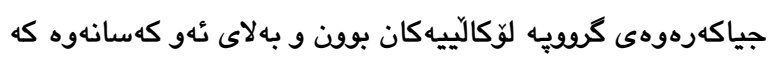

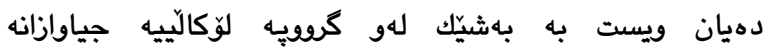
مه زمارنهكريّن، بهكارهينّاوه

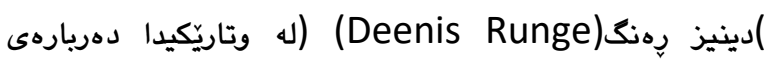
فكرهكانى ثيبهر دهليّت : مـبهستى ثيبهر له شيّوازى ثيان ، به هاو ريّو ره سميّكى هاويهشه كه مهستى شوناسيهكى هاويهش به گروبي

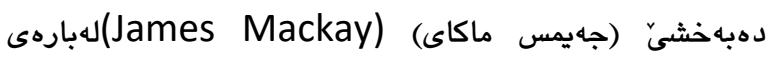
ديدكاى ثيبهرهوه دهليّت: مهبهستى ثيبهر لهشيّوانى ثيان ئهو ريّبازانهن كه هين و كروبيه هاوريّكهكان له زياندا خولقاندويانن. ئه م بابهته (شيّوانى ريان ) يِيّاسيّكه كه سنوودى ناديارى نيّوان

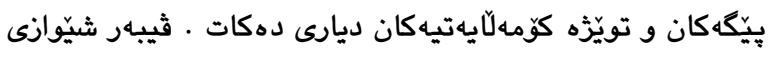

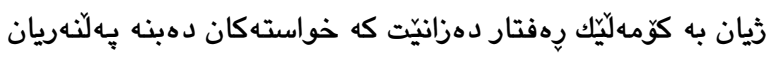
و دهرفهتهكانى زيان يِانتاييهكن بوّ دهركهوتنيان. بهههمانشيّوه

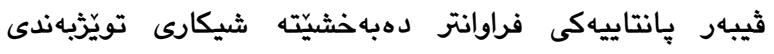

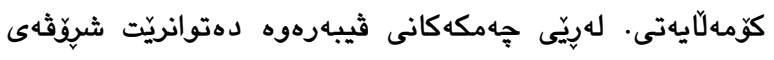
نايهكسانى جياوازيهكان له ئاستى ستوونى و ئاسوّييدا بكريَت. بوّ

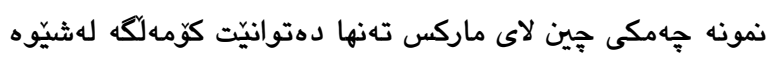


نووسرابيّت و سوودى له بوّجوونه كانى ئهو وهرنه كرتبِّت، هـر لهبهر

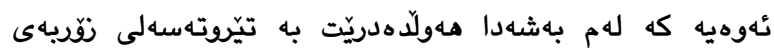

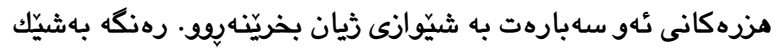

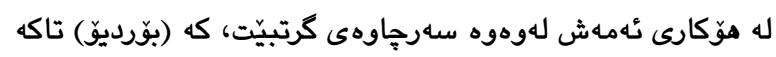

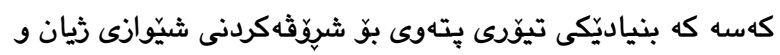

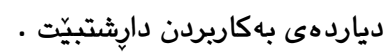

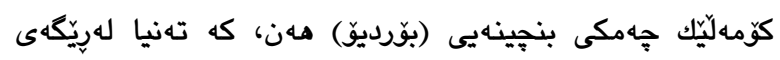

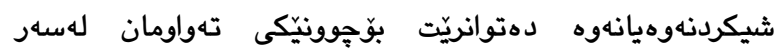

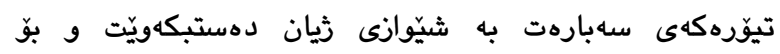

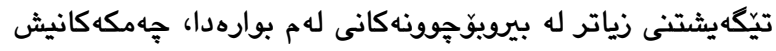

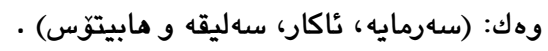

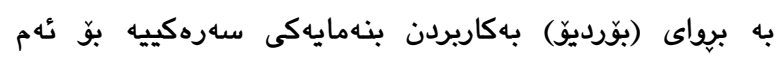
سهردهمه و لهويارهيهوه خوكرتنى تاكهكان له دروستكردنى

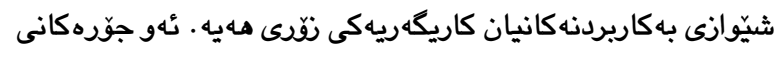

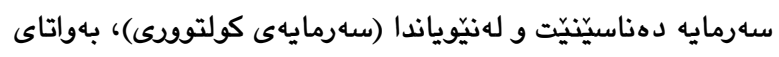

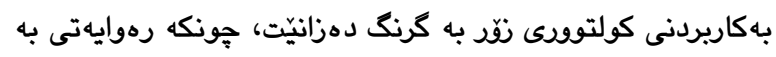

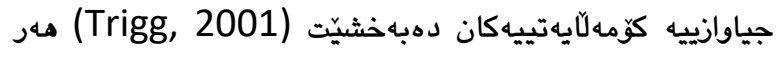

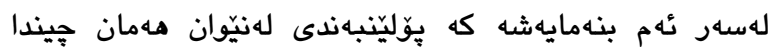

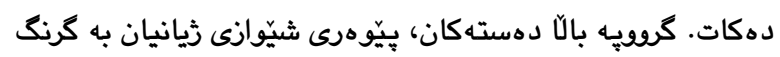

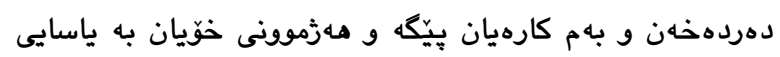

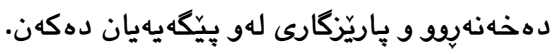

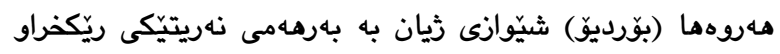

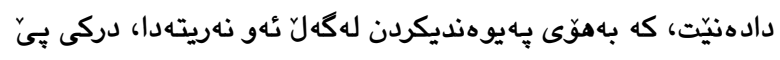

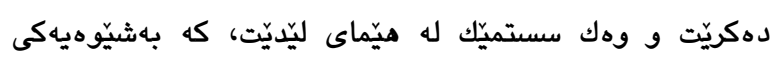

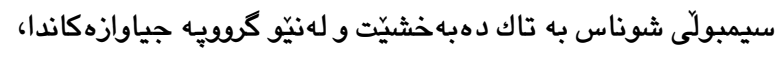
جياوازى دروست دهكات. كهواته، نهريت و سهرمايهكانى تاك له

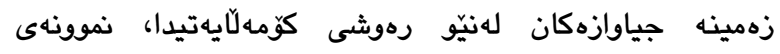

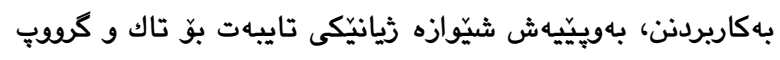

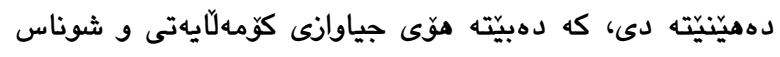

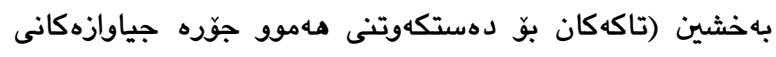

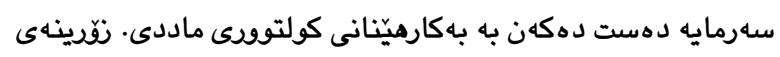

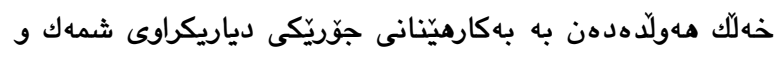

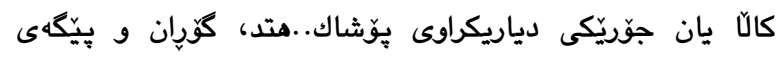

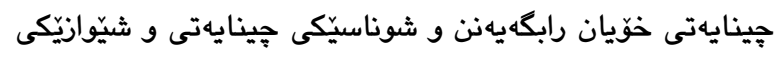

نويَيى ثيان وهدهستبخهن).(Bourdieu,1984)

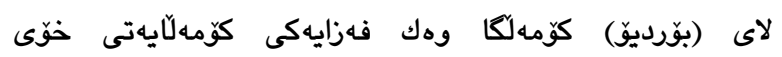

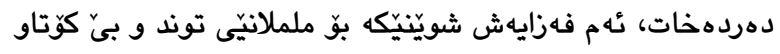

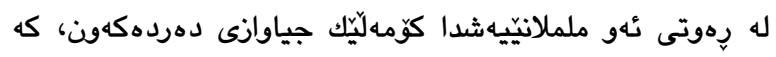

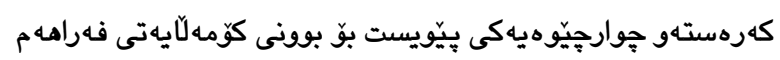

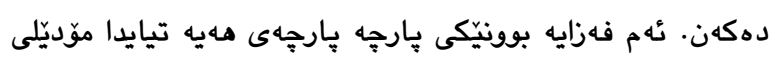

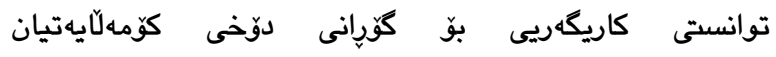

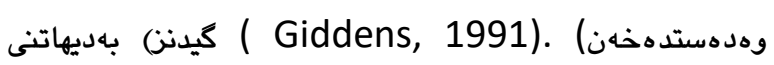

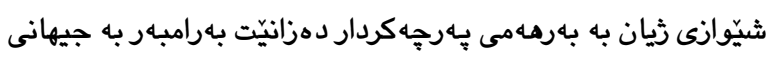

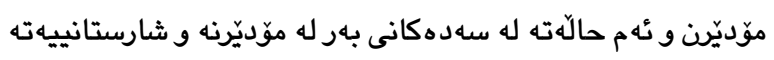

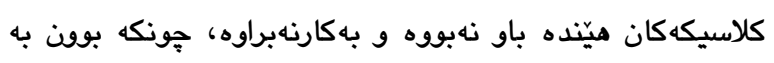

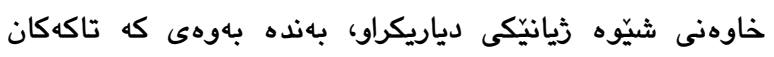

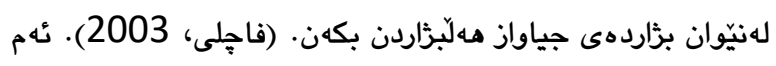

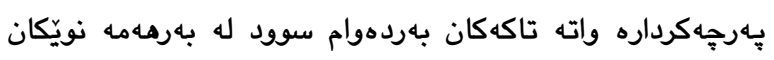

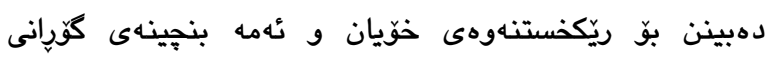

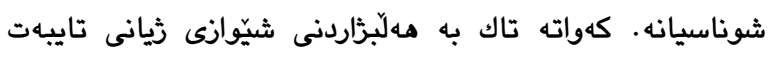

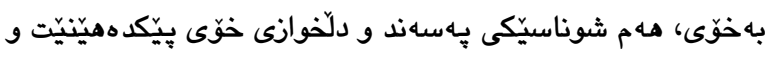

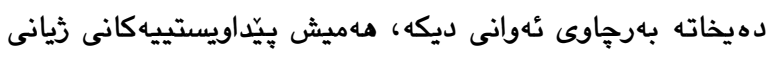
خوّى دابين دهكات.

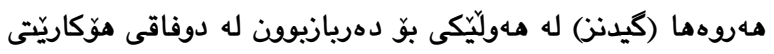

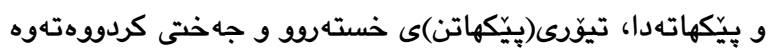

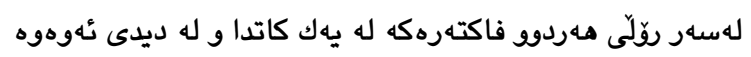

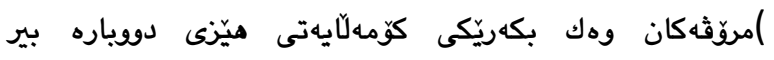

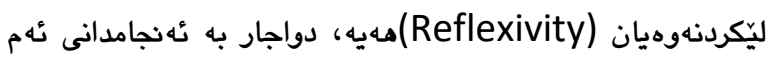

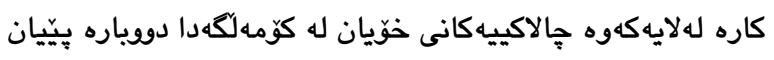

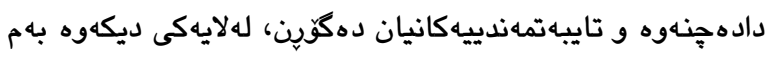
كارهيان تواناى كاريكهريى بو كوّرانى دوّخى كوّمهلآيهتييان

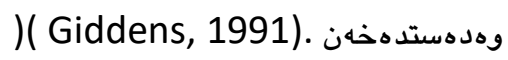

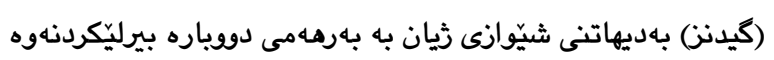

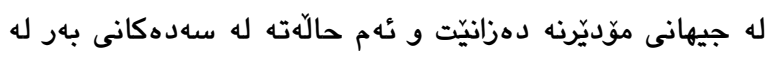

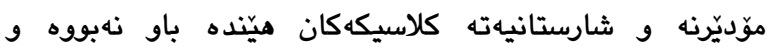

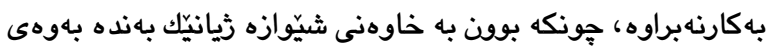

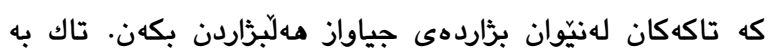

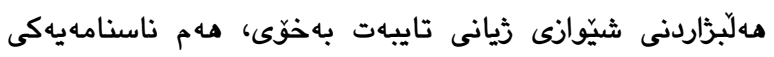

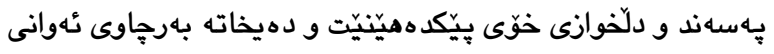
ديكه، هـميش بِيّداويستييهكانى ثيانى خوّى دابين دهكات.

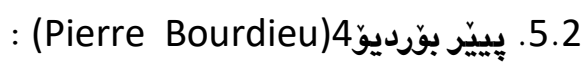

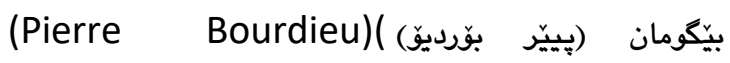

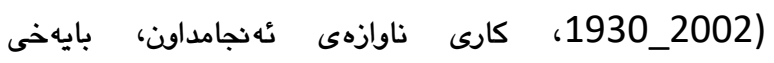

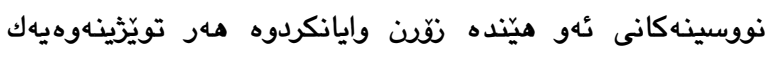

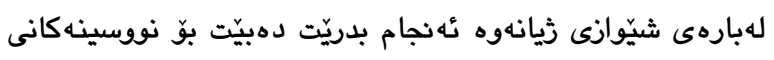

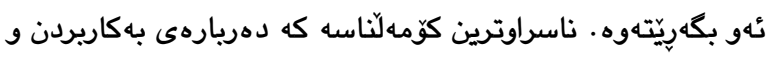

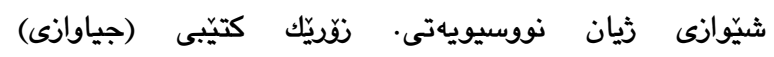
(Distinction)

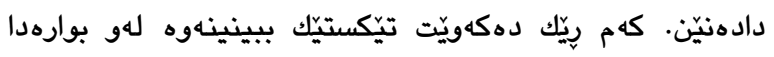


زيانيّكه كه براردهى سهرگهرميان بريتيه له خليسكهى سهر ناو،

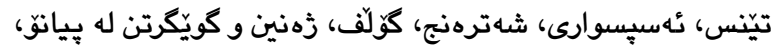

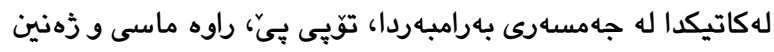
و كويّكَرتنه له ئوّكورديوّن. ئهو نيشانى دهدات، كه هـر له له

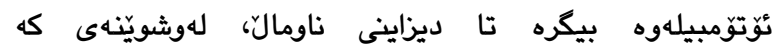
دهستنيشانكراوه بوّ ويّنهُرتن تا ئهو شتهى كه تاكهكان دهيخوّن و دهيخوّنهوه، ئاراستهيهكى ناجارى كوّمهلاّيهتين بوّ تاكهكان

(Bourdieu,1984)

كهواته تيّبينى دهكريّت كه به ديدى (بورديوّ) شيّوازى زيان بهشيّوهى هيّمايى شوناس دهبهخشيّته تاك و لهنيّو تويَّه كوّمهلايهتييه جياوازهكاندا جياوانى دهخولقينيّت. بهو واتايهى

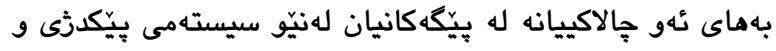

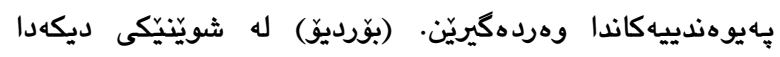
شيّوازى ثيان بهو مانايه دادهنيّت، كه له رِيّيهوه خاوهن بِيّكه جياوازهكان بهمهبهست يان بى مهبهست خوّيانى يَّ لهوانى ديكه

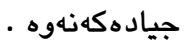

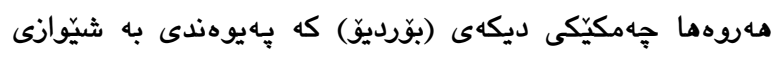
ثيانهوه ههيه بريتيه له (هابيتوس) . (Habitus) به لاى ئهوهوه واقيعى زيانى كومهلكا دوو ئاستى ههيه، يهكهيان كايه كوّمهلاّيهتييهكانن، ئهمانه دهكهونه دهرهوهى تاكه كانهوه و بنيادى سهربهخوى خوّيانيان ههيه. ئاستى دووهميش بريتيه له واقيعى

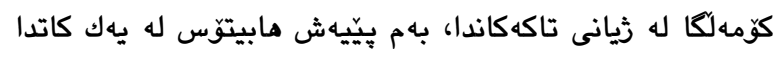
بوونى واقيعى كوّمهلكا و كايهكانه له جهستهى تاكدا. لایى (بوّرديو) هابيتوّس بريتيه له سستميّك و تاكهكان بههويهوه له جيهانى

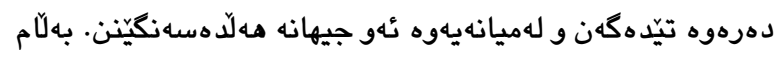

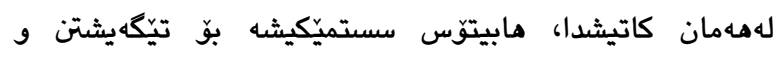

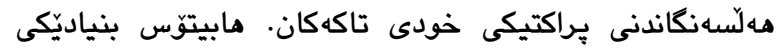

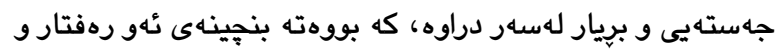
بيركردنهوه و جوّرى مهلَّرَاردنانهى تاك له ثريانى كردهييدا ئهنجاميان دهدات (كرنفل، 2008).

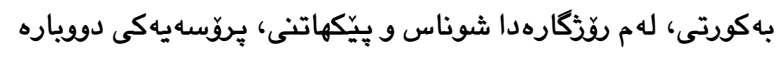

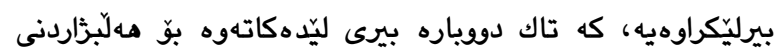

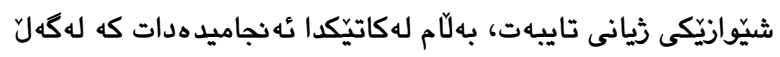

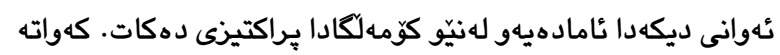

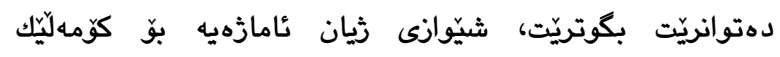

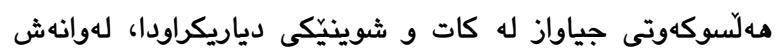

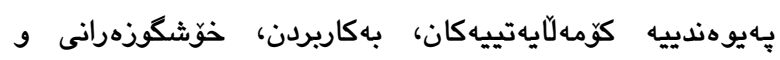

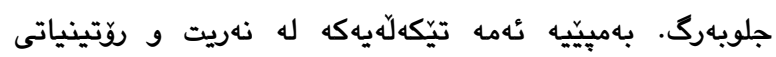
ئهنجامدانى شتهكان و كارِايى ئهلّلّبر، كه دهتوانريّت له رهفتارى

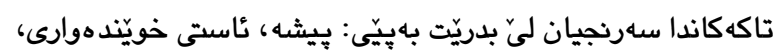

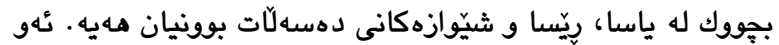
موّديّله بجووك و جياوازانه بِيِيان دهوتريّت كايه (مهيدان). كايه

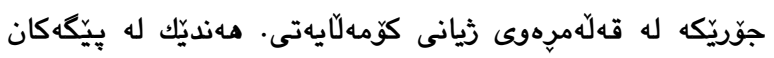

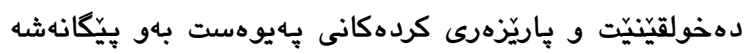

(Bourdieu,1984).

ئاكار، يهكيّكه لهو جֶهمكانهى (بوّرديوّ)، كه زِّرترين مشتومريى لهسهره و بوونى بنجينهيى شيكارى (بورديوّ) بوّ كردهكانى مروّث

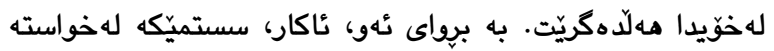
بهردهوام و كواستراوهكان، كه وهك كارى بهرههمدار، بنيادنهر و بهرئ بهشيّوهى بهرجهستهبوو يوّلّ دهبينيّ. لایى (بوّرديو) نئاكار، بنيادنهر و مهمامهنگ به خشى ههلومهرجى ناوهكى جينه كانه . ئاكار وهك ريّسايهك دهردهكهويّت كهوا له مروّثهكان دهكات كوَنتروّلَّى رهفتارهكانى خوّيان بكهن (كرنفل، 2008)

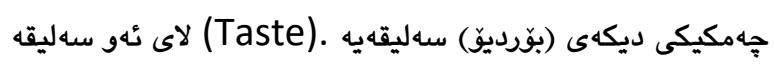
بريتيه له مهلومهرجيّك يان كارامهييهك له ميانهيهوه رستيك له شمهك يان كردار بهشيّوهى ماددى يان هيّمايى بهناونيشانى

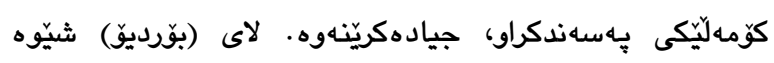
جياجياكانى خاوهنداريكردنى سهرمايه لهناواخنى يهك جيندا، بريتيه له بوونى سهليقهى جياواز. ئه گرجى له روكهشدا سهليقهكان بهشيوهى سهربهخو و لهنيّو فهزاى كوّمهلآيهتيدا

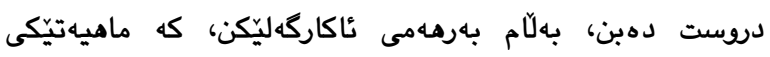

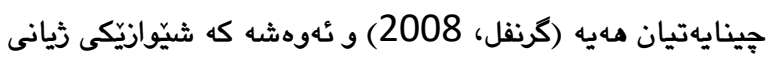

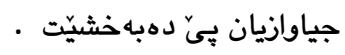
يه كيّك له جهمكه كليله كانى (بورديوّ) كه (جياوانى)يه، به مجوّره يِيناسه دهكريّت (جياوازى بهماناى كوّمهليّكَ جياكردنهوه ديّت، كه

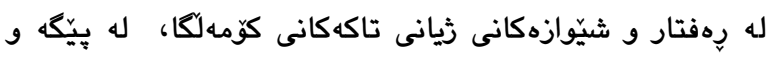
لهلايهنى سهرمايه و بوونيان له كايه كوّمالّايهتييه جياوازهكاندا، رهنگ دهداتهوه). له يوانكهى (بوّرديوّ)وه، مهموو ئهو شتانهى

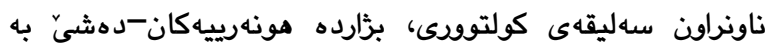

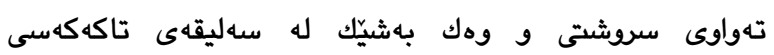

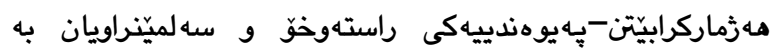

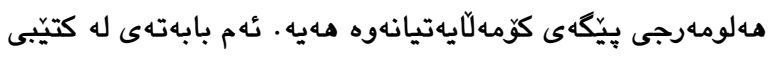
(جياوازى)دا كه بهرهـمى تويَزَينهوهيهكى مهيدانى تيّر و تهسهله،

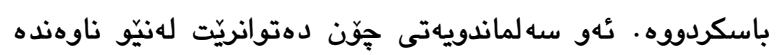
جياوازهكانى وهك وهرزش، خَراك، جلويهرگ، سهليقهى هونهرى،

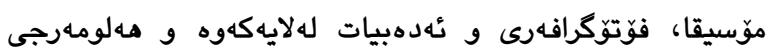
كوّمهلايهتى تاكهانيش لهلايهكى ترهوه، يهيوهندييهكى لوَرَيكى

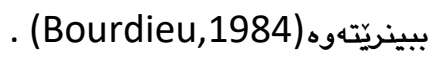
(بوّرديو) نئهوه دهخاتهِوِ، كه له كوّمهلكايهكى وهك فهرهنسا

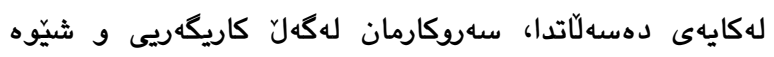




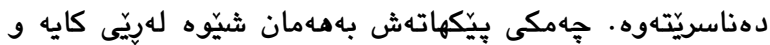

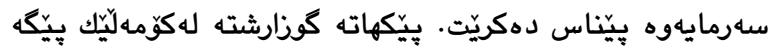
كه بهسهرنجدان به قهباره و شيّوهى سهرمايهكهى ناوى، شايانى

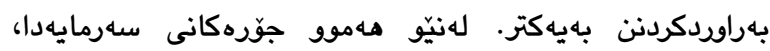

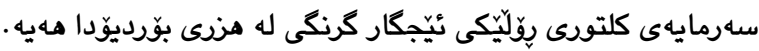
كوّمهالَّاسى بهكاربردن و شيكارييهكهى دهربارهى شيّوازى ثيان، لهسهر سهرمايهى كلتورى بنيادنراوه. سهرمايهى كلتورى هـمور

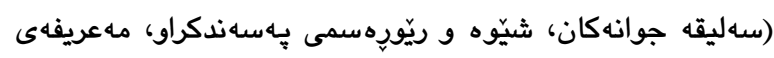
بهيهكداجوو و تواناى وهركرتنى بهرههمه كلتورييهكان، يِّوَّهى

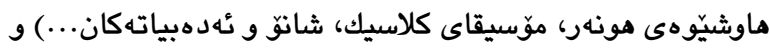

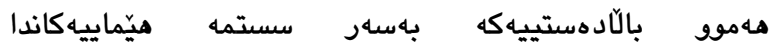

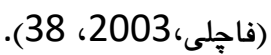

شيّوه جياوازهكانى سهرمايه لاى بوّرديوّ، به رهكهنى دروستكهرى بنيادى كايه كانى دهزانيّت. كايه ، يهكيكه لهو جهمكانهى بوّرديوّ كه نِّرترين مشتومريى لهسهره و بوونيّكى بنهينهي شيكارى بوّرديو

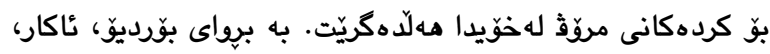
سستميّكه لهخواسته بهردهوام و كواستراوهكان، كه وهك كارى

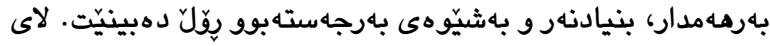

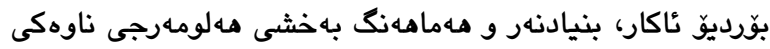
جينهكانه. كايه وهك ريّسايهك دهردهكهويّت كهوا له مروّثهكان

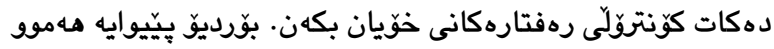

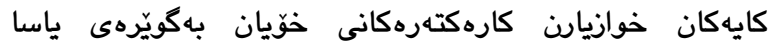
كردارييهكانى نيّو كايهكه بجوليّنهوه. كايهكان له كارهكتهرهكانى خَويان داواكارن كه ياساكان بهثيّوهيهكى كارامه لهنيّو توَيىى يَهيوهندييهكان، كوَنتوِّلَى ياسا نهنووسراوهكان، شيَوهى كرده لهنيّ كايهكه و كوتارى زهينى داوهرييهكان، كه زهمينهى تيُكهيشتن لهبابهتهكان دهسازينن، لهلايان رهنكبداتهوه. كايه

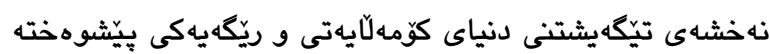

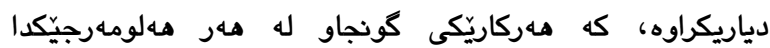

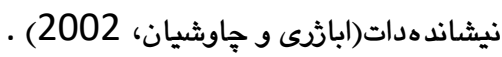

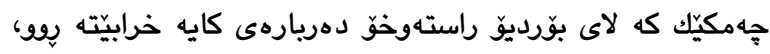

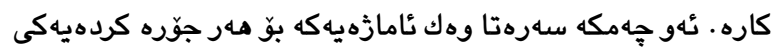
مرّقُ. كرده جوّره بهنهريتبوونيّكى رهفتاره، كه جههندين بهشى ههيه: شيّوهى هالاكييه جهستهييهكان، شيّوهى هالاكييه زهينييهكان، شتهان و ئهركهانيان، مهعريفهى سهرهتايى

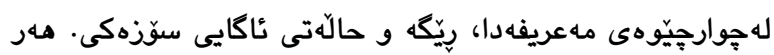
كرداريّك يشت به كوّمهليّك توخم دهبهستيّت، كه بهسهريه كهوه وهك سندوقيّكى يِّ له كهرهسته وان. كرده، جوّره رهفتاريّكى بهنهريتبووه، كه له كوّمهليّك بهشى جياجيا دروستبووه. كرده، كايهى بهيراكتيكبووه. جهختكردنهوه لهسهر جهمكى كار، زقرى

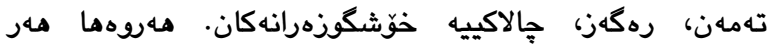

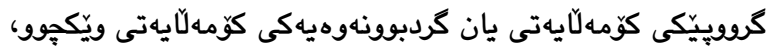

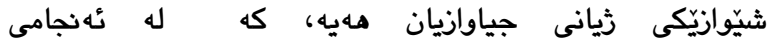

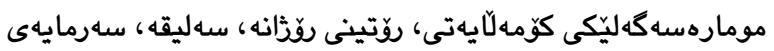
كوّمهلّايهتى، نابوورى و كولتوورييهوه پِهيدا دهبن.

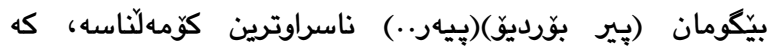
دهربارهى بهكاربردن و شيّوازى ثيان نوسيبيّتى. نِّيَك كتيّى (جياوازى) ئهو به ئينجيلى تويّزَهرانى ئهو بوارهى دادهنيّن. كهام

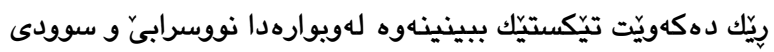
له بوّجونهانى ئهو وهرنه كرتبيّت. بهشيّك له هوَكارى ئهمه رهنكه لهوهوه سهرجاوهى كرتبيّت، كه بِورديوّ تاكه كهسه تيوّرى

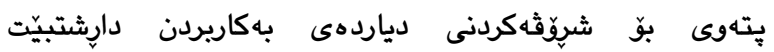
(فاجلى، 2003)

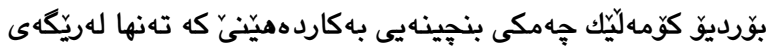

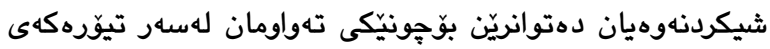
دهستكهويّت لهخويّندنهوه بوّ كوّمهلّاسى بهكاربردن بوّرديو و

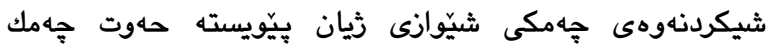
شيبكريّنهوه واتا (كايه، سهرمايه، ريّياز، كار، هيّما، جين و و سهليقه). لاى بوّرديو كوّمهلكه وهك فهزايهكى كوَمهلايهتى خوّى دهردهذات، ئهم فهزايهش شويّنيّكه بوّ ململانيّى توند و بيّ كوَتا،

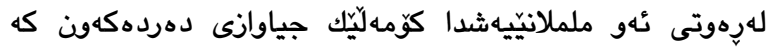

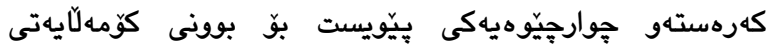

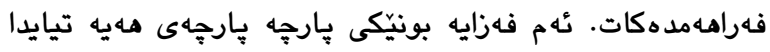

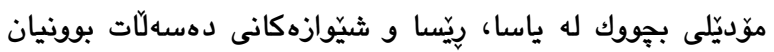
ههيه. تئهو موّديّله بجووك و جياوازانه بِيِّانهو دهوتريَت كايه

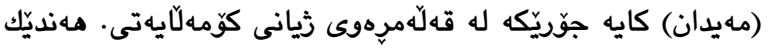

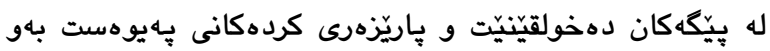
يَّيَانهشه (اباثرى و جاوثيان، 2002).

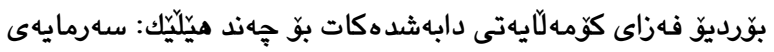
تابوورىى، سهرمايهى كوّمهلّايهتى و سهرمايهى كلتورى و هيّمايى.

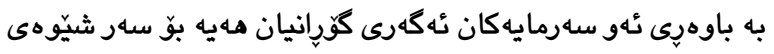

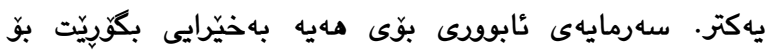
سهرمايهى كوّمهلآيهتى و سهرمايهى كلتورى و هيماييش.

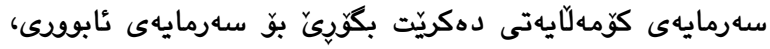

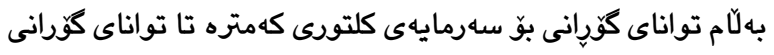

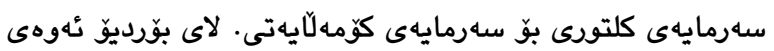
مانا دهدات به كايه" سهرمايهيه

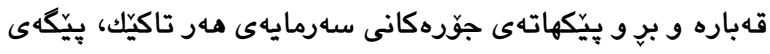
وى له يّله بهندى نيّو كايهكها ديارى دهكات. بهواتايهكى ديكه، مهر كايهيهك لهريّى جوّر و قهبارهى سهرمايهى مهبوو لهنيّويدا 
دووهميش بريتييه له واقيعى كوّمهلكه له زيانى تاكهكاندا، بهم يِيّيه شابيتوّس له يهك كاتدا بوونى واقيعى كوّمهلكه و كايهكانه له جهسته تاكدا. لالى بوّرديو هابيتوّس وهك ستميّك يِيناسه

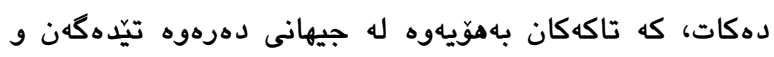

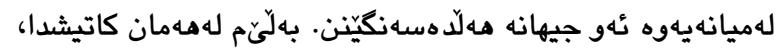

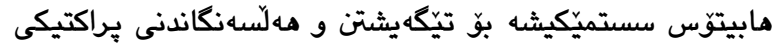
تاكهكان خوّيان. مابيتوّس بنياديّكى جهستهيى و بريار لهسهر

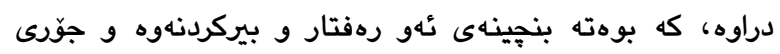

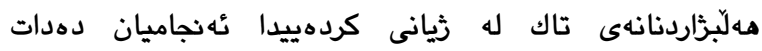
(Bourdieu,1998) شيّوازى ثيان ئامازهيه بوّ كوّمهليّكَ مهلّسوكهوتى جياواز له كات و شوينيّكى دياريكراودا، لهوانهش يهيوهندييه كوّمالّايهتييكان،

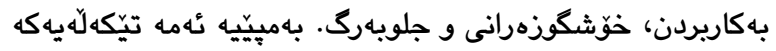
له نهريت و روّتينياتى ئهنجامدانى شتهكان و كاريايى ئهقلّبر، كه ونه دهتوانريّت له مومارهسهردنى رهفتارى تاكهكاندا سهرنجيان ليّ بدريّت وهك: پيشه، ئاستى خويِندهوارى، تهمهن، رهكهز، جِالاكييه

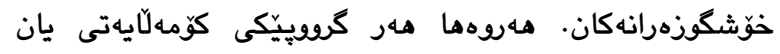

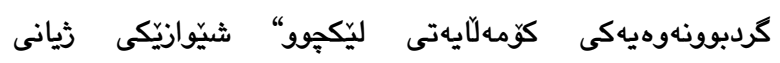
جياكراوهيان مهيه، كه له ئهنجامى مومارهسه كهليَكى كوّمهلّايهتى،

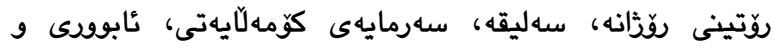

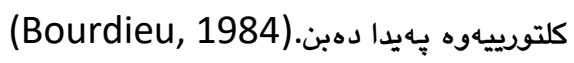

\section{3. يِيناسهى شيّوازى ثيان}

دهكريّت تهواوى پِيِناسهكان (دابهشى سهر دوو كرووي بكرينين و

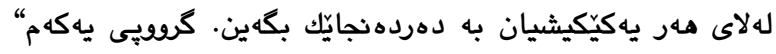

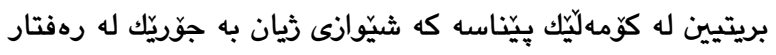
مهزمار دهكهن و بهها، تيّروانين و ئاراسته دهروبونييه كانى تاكهكان دهخهنه دهرهوهى بازنهى ئهم جههكهوه. ئهم يوانكهيه، بهواتاى

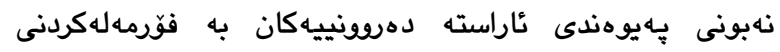
شيّوازى زيان نايهت، بهلكو واتهى نئهوه دهكهيهنيّت كه كرنگ نييه

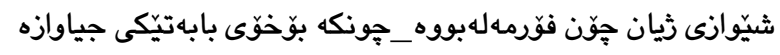

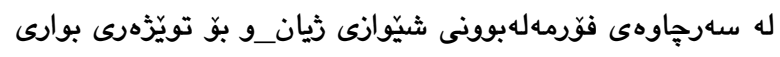
ناسينى شيّوازى ريان كه لهسهر بنهایى جياكردنهوهى هـنديّك لهرهفتارهكان (بهههندى تايبهتمهندى دانسقهوه) دروستبووه،

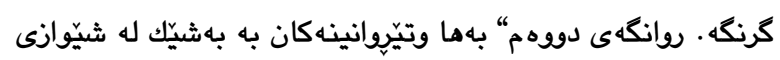

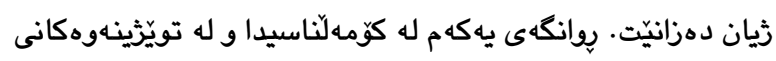

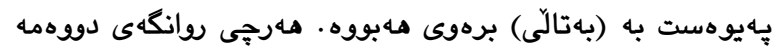
روكاريّكى دهرونتاسانهى ههيه و لهنيّو دهرونتاسيدا و

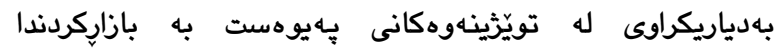
دهركهوتووه.
مهيلى بوّرديوّ بوّ خويّندنهوهى رهفتارهكان لهسهر بنجينها ئهقلّى

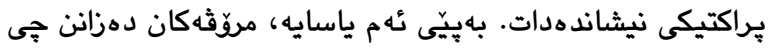
دهكهن، بهلام بهُشتى ناتوانن ئهو كردارهيان رون بكهنهوه (مهدويكنى، 2007). هيّما، يهكيّكه له نموونهكانى جياوازى بوَرديوّ له ماركس. ئهو لهجياتى باسكردن له هيّما، دهربارهى (بابهتى هيّمايى) دهدويّت. بابهتى هيّمايى" شتيّكى مادييه، بهلاّم ئهو بهوهما تايبهتمهندييهك

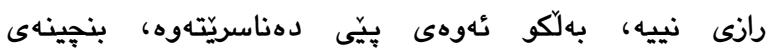
كاركردنهكهيهتى. بهتيِيوانينى بوّرديوّ، بابهتى هيّما لهتوانايدايه،

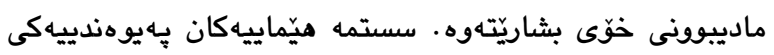

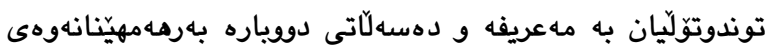

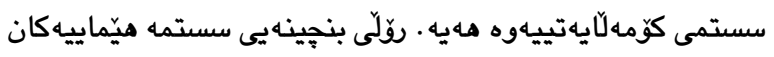

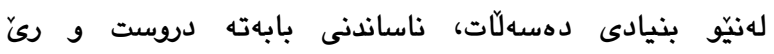

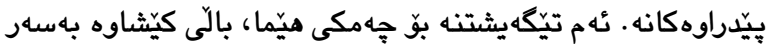
تهواوى بوّجوونهكانى بوّرديّدا، نئهيش له كتيبى جياوازيدا

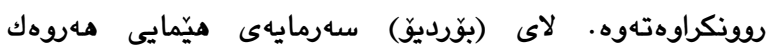
سهرمايهكانى ديكه تهماشا دهكريّت، ئينجا لهبهر ئهوهى مهر يهك لك له جوّرهكانى سهرمايه_كوّمهلآيهتى، ئابوورى و كلتورىى_به يـلهى جياواز، وهك سهرمايهى ميّماييش بهرجهسته دهبن، ئهوه دهكريّيت

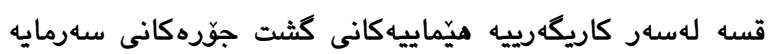
(Bourdieu,1984يكريت بوّرديو جين به كوّمهليّكَ كارهكتهر بِينّاس دهكات كه كهوتوونهته يِيّكهى كوّمهلّايهتى وهك يهكهوه و كهوتنه نيّو مهلومهرجيّكى ماويهش و رهنكه خواست و يهيوهندى وهك يهكيان مهبيّت، لهبهر

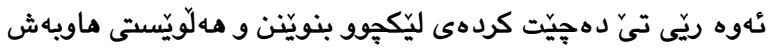
وهريگرن. بنهماى دروستبوونى يهكيتى جين، ئاكارى هاويه شيانه. كايهى جينايهتى، يهيوهندى ناسوّيى و جياوازى ستونى له فهزاي

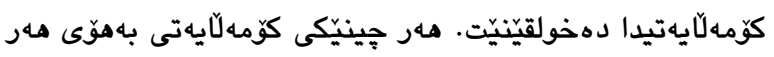

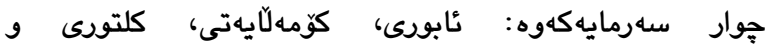
هيّماييهكهيهوه دهناسريّتهوه. لهراستيدا، بوّرديوّ لهسهر بنهاى

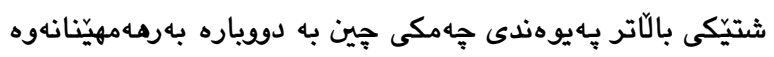
لهنيّو فهزاي ئابووريدا، خويّندنهوهى بوّ دهكات. ئهو هـميشه جيّنى

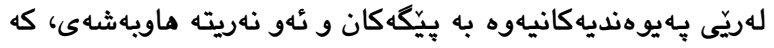
له فهزاى بهكاربردندا كارايه، يِيناس دهكات و بهكاربردنيش به جوّريّك له ململانيّ دهزانيّت بوّ بهدهستهِينانى سهرمايه، كه له

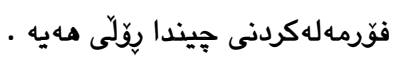

ههرهها جهمكيكى ديكهى بوّرديو بريتييه له (هابيتوّس) (Habitus).

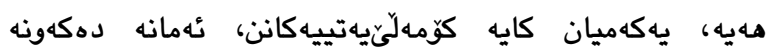

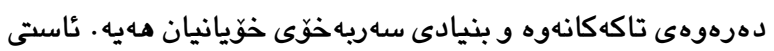


بايهخدان به لايهنى دووهم، واته رههدنده كوّمهلّايهتييهكهى جين

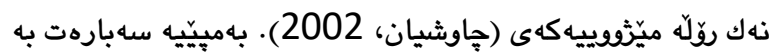

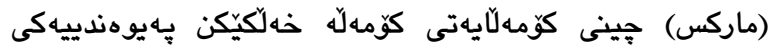

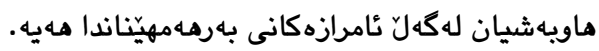

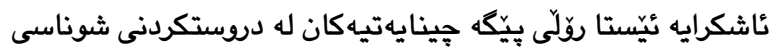
تاكهكاندا كهمبووهتهوه، بوّ نموونه بهشدارى تاكهكانى نيّو هِين له بزوتنهوه كومهالّايهتييهكاندا ئهوهمان يشاندهدات كردهى تاكهكان و خواست و يهيوهندييهكانيان له رياندا جياواز له رابردوو لهسهر بنهماى براردهى خوّيانهو، تاكهكان به تهواوهتى لهزيّر كاريكهريى يِيكّى جينايهتى و بكرهوهندييه ئابوورييهكانيان، (Arslan, 2011). كرده نانويّنن

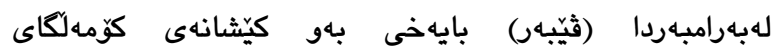

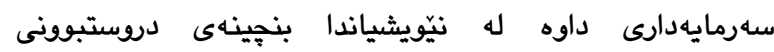

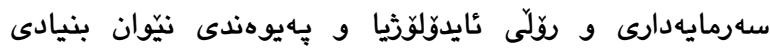

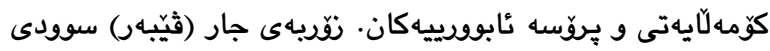

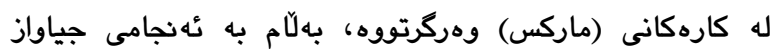
كهيشتووه مهروها له رونكردنهوهى جهـمكهان و لايهنه خودييهكانى دابه شبوونى جينايهتيدا ديسان نئنجامى جياوازترى دهستكهوتووه.(Galobardes el al, 2003) (ثيّبهر) وهك (ماركس) جهختى كردوهتهوه لهسهر جياوازى نيّوان ئهوانهى خاوهن سهارمايهن و نٔهوانهشى كه خاوهن هيج شتيكّ نين. مشتومريى (ثيّبهر) سهبارهت به جينه كوّمهلايهتييهكان پشت دهبهستيت به بابهتيبوونى مهرجه ئابوورييه دياريكراوهكان

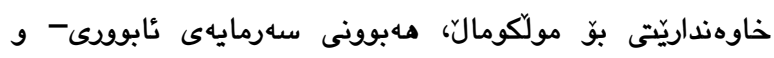

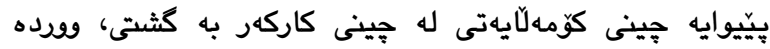
بوّشواكان و روّشنبير و تهكنيككارهكان و فهرمانبهره خاوهن يهخه سييه جياوازهان و ئهو جينه جياوازانهى له ميانهى سهرمايهو

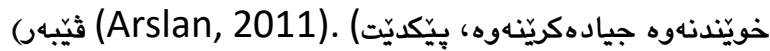
لهزيّر سستمى سهارمايهداريدا مشتومريى جِينى كوَمهلَّايهتى دهكات، به يشتبهستن بهوهى تا جههنده خاوهنى سهرمايهن يان نا، دواجار ئهم كوزارشت دهكات لهسهر كوزهركردن بهرهو جينه بهرزهكان له ميانهى به هرهمهندى وهركيرا و و يِيشكهوتن و ئاستى خويّندنهوه.

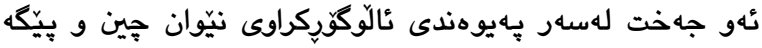
دهكات و جهخت لهسهر بهيوهندى نيّوان نابوورى و كوّمهلكا دهاتهوه. (مهديكنى، 2007)

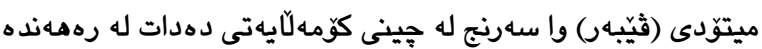
جوراوجوّرهكانى وهك: جياوازى كوّمهلّايهتى، خاوهنداريّتى، بِيشه،

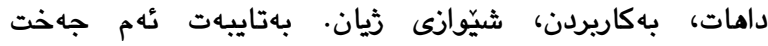
كردنهوانهى (ثيّبهر) لهسهر شيّوازى زيان و شيّوازى بهكاربردن، كاريخهرييان ههبووه لهسهر تيوّره كوّمهلّايهتييه نويّكان، كه
هـموو ئهو كروويانهى كه لهكوتى جالاكييه نه ريتييهكان نازادبوون، برَاردهى جوراوجوّريان بو دهستنيشانكردنى شيَوانى ريان لهبهردهستدايه . ئهوه ش شتيكى سروشتييه كه جياوازى شيّوازى ئى ثيان له نيّوان كروبيهكاندا، بهوجوّرهيه كه بوّرديو جهختى لهسهر كردووهتهوه . (Giddens 1991) به باوهيى هنديّك له

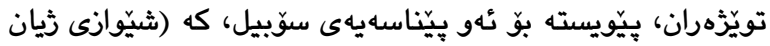
كوزارشته لههدر شيّوهيهكى زيان كه جياواز و دهستنيشانكراو دهبيّت) ئهو خالَه زيادبكريّت كه ئهو شيّوه زيانه بِيِويسته لهنيّوان

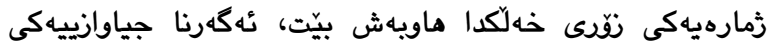

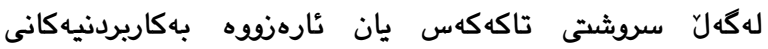

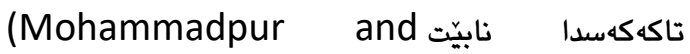
Mahmoodi,2016

\section{4. جين و شيّوازى زيّان}

جينايهتى يهكيّكه لهو بابهتانهى بهردهوام جيّكهى مشتومريى

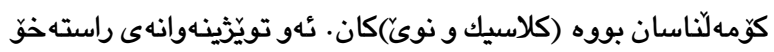
يان ناراستهوخوّ كار لهسهر بابهتى هينايهتى دهكه، وايِيَويستدهات سهرهتا بوّ نووسينهكانى (ماركس) بكهرينهاهو سهبارهت به جينى كوّمهلآيهتى.

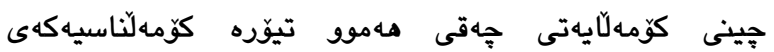
(ماركس)ه. تئهو جينه سهرهكييهكانى كوممالكاى سهرمايهدارى موّديّرنى خستووهته يوِ بهوهى خاوهن هيّزى كار خاوهن

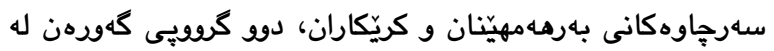

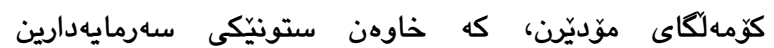
(Crompton, 1996, p. 187).

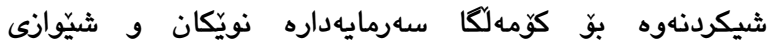

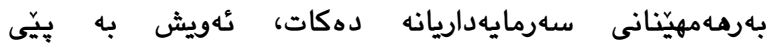

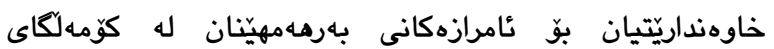
سهرمايهدارى يِيشه سازيدا له يهكيان جيا دهكاتهوه، لاى ئهو بورثوا

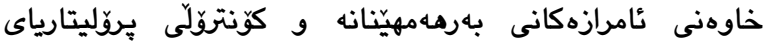
كردووه، له بهرامبهردا لهسهر يُروّليتاريا وا يِّيويست دهكات كارى

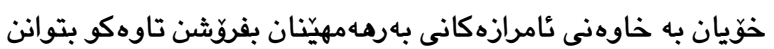
له بهرامبهردا دهستحهيّك وهريخرن، دواجار بتوانن له زياندا

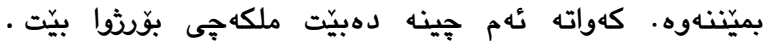
(Wacquant, 1991) . جينى كوّمهلاّيهتى لایى (ماركس) كهرهستهيه كه بو شيكاركردنى دوو

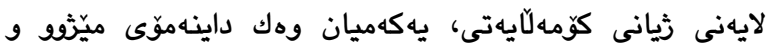

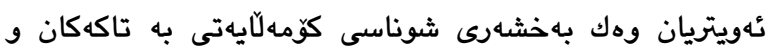

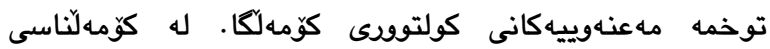

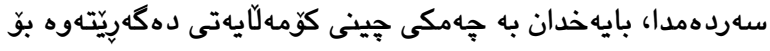


دابه شكرى وقرد مهيه و دابه شدهبيّت بوّ كرويِى كوّمهلآيهتى ديكه.

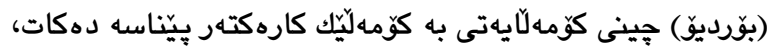

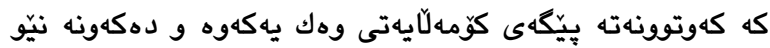

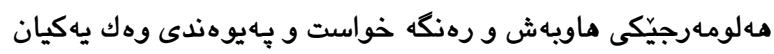

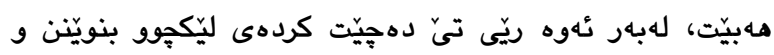

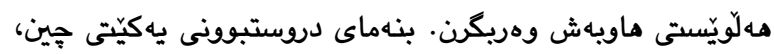

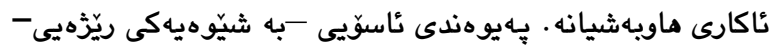

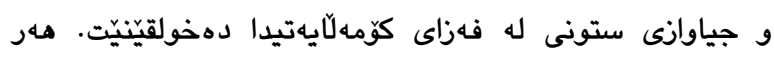

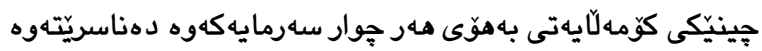

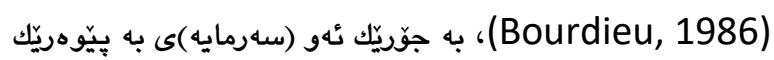

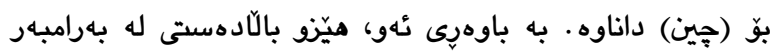
تُهوانى ديكهدا به تهنيا له خاوهنداريّى سهرجهاوه ماددييهكانهوه

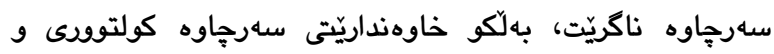

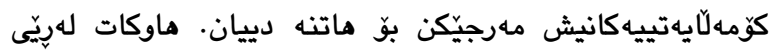

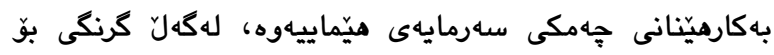

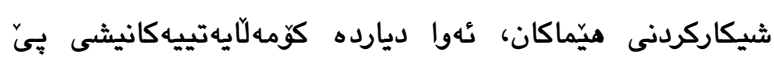

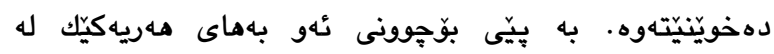
شيّوهكانى سهرمايه تارادهيهك به مهعريفهى كوّمهلايهتييهوه

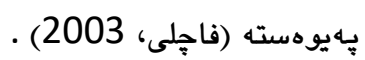

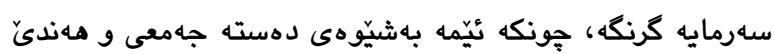

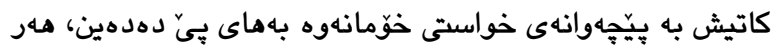
ئهمه وادهكات مهلومهرجيّك بيّتهايهوه، كه سهرمايهكهمان

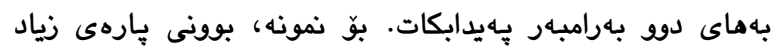

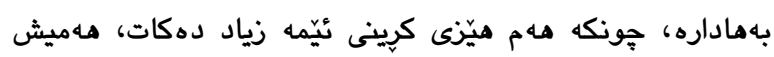

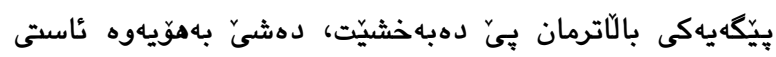
سهرمايهكانى ديكهش بهرز ببنهوه . (بورديوّ) له ئه نجامى رستيّك تويَزينهـوه لهبارهى سهليقه و باشترين كولتوود (1) بهو ئهنجامه گهيشت كه يوّلّى كولتوود له كوّمهلكا نويّكان يشت دهبهستيّت به سهليقهى مهر جِينيّك، ئهم حالَّته جّريّك له جياوازى جينايهتى لهنيّوان كروبيه مروييهكاندا دروست

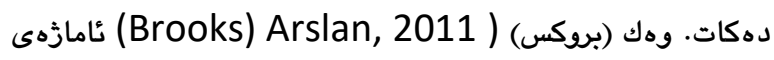

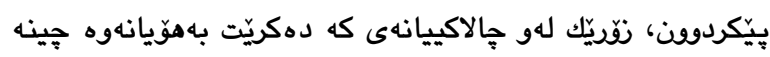

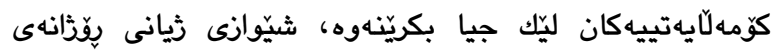

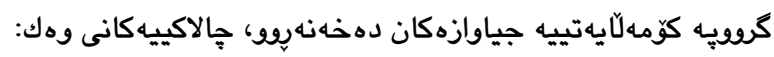
ئهندامبوون له سهنديكا يان ريّكخراويّك، نهريتهكانى خوّشكوزهرانى

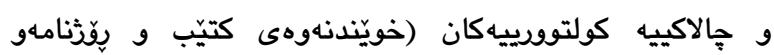

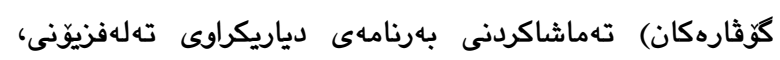
جوونه سينهما، تُاههنگ و كوّنسيّرت و كوّرى شيعرى يان

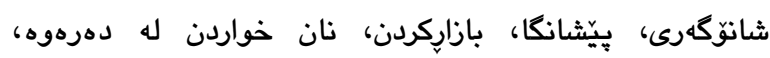
ميوايهتهكان، بهسه ربردنى كاتهكانى يشوو و گهشتكردن، ئهمانه

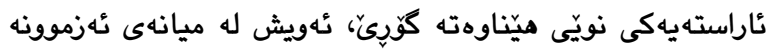
كوّمهلايهتى و كولتوورى و سياسيهكانهوه (انغليز و هيوسون،

دواى ميراته هزييهكه هدريهك له (ماركس و ثيّبهر)، له ئهنجامى

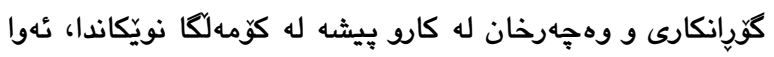

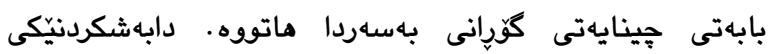

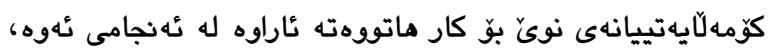

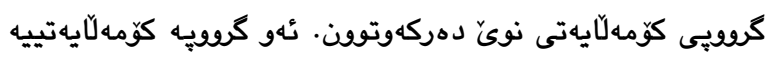

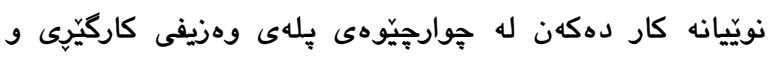
جيّبه جيَ كار، له سهرمايهداران و جينى كريّكاران، جياوانن له كرويـهانى ديكه.

ئهميوّ، هِين وهك جههمكيكى نزيككراوه بهكارهاتووه له نيّو تيوره

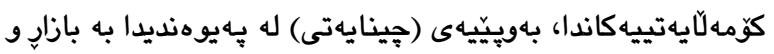

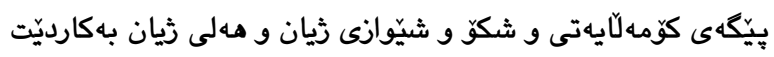

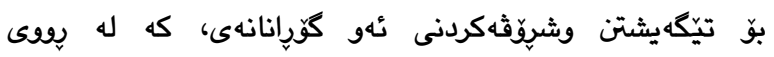
كوّمهلايهتى ئابوورى و سياسى و كولتوورييهوه له كوّمهلكادا يوينيستاش خاوهن ئامرازهكانى بهرههمهينان ههليهرستى له خاوهنداريّتى كالّاكان و بهكاربردن و شيّوازى ثياندا دهكهن و له ثيّر سيّبهرى سهرمايهدارى نويّدان،

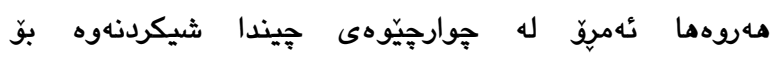
بهرفراوانبوونى يِيشهكانى ديكه كراوه، كه دهستى نين، شيكردنهوه بو شيّوازهكانى بهكاربردن و شيّوازهكانى زيان كه ماوشيّوه نين،

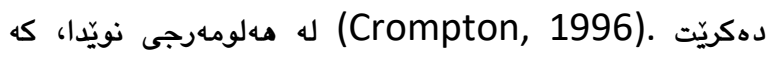

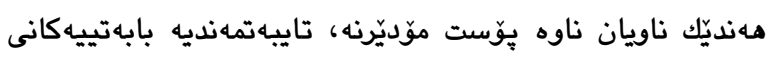
جينهكان به مهامان شيّوهى رابردوو ماونهتهوه، بهلام تايبهتمهندييه خودى و دهرونييه كانى جينه كؤمهلآيهتييهكان بهشيّوهيهكى كشتى كَّرِاون (انغليز و هيوسون، 2013) .

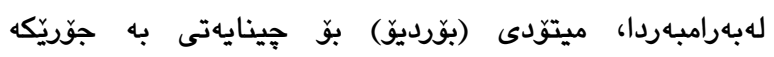

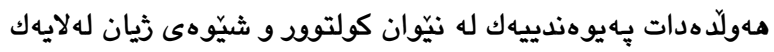

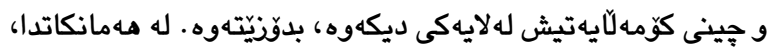
ئهو بهرامبهر يِيّويستيه هنهوركهييهكان بو شيكاركردنى جينه

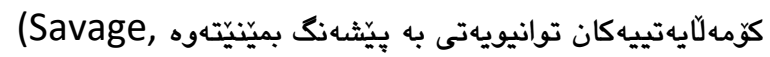

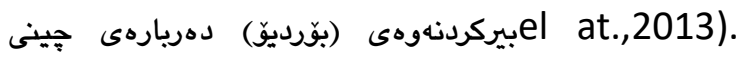

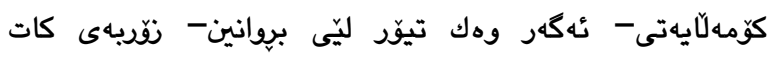

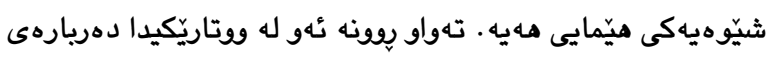
جين ئهوه يوون دهكاتهوه، كه بهوكارهى دهيهويَت خوّى له داوى شيكارى ماركسيانه نازاد بكات . (Bourdieu, 1986) بوّ نموونه

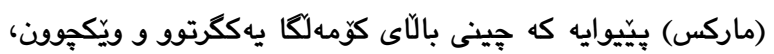

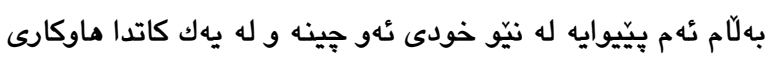

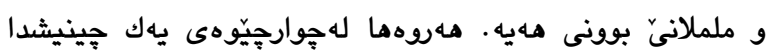


-بّوشواى ئابوويى: ئاستيّكى مامناوهندى سهرمايهى كولتوورى

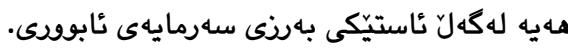

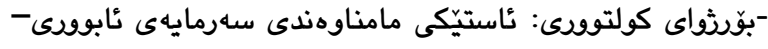
بهبهراودد به بوّرثواى تُابوورى - و ئاستيّكى بهريى سهرمايهى كولتوورى. 2_جينى ناوهندى خوارو (وودده بورثوا): ئاستى سهرمايهى كولتوورى مامناوهند و تا ئاستى كهموكورت، للكهلَ سهرمايهيهى تابوورى مامناوند تا ئاستى كهمووكورت.( انغليز و هيوسون، (2013 3 ئابوورى كهموكورت. لهراستيدا (بورديوّ) لهسهر بنهماى شتيّكى بالَّتر خويَندنهوه بوّ

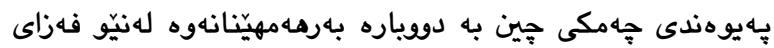

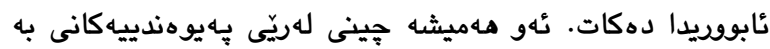

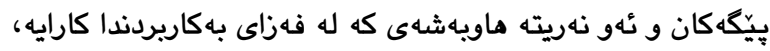
پيّناسه دهكات. مهروهما بوّ (جياوازى جينايهتى) تهنيا رههدندى

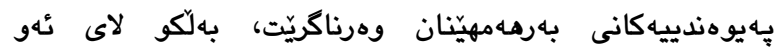

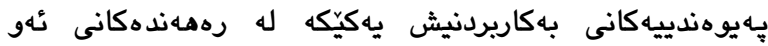
جياوازيه.

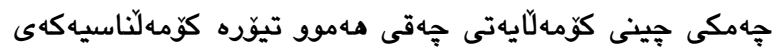

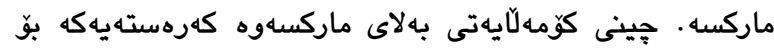
شيكاركردنى دوو لايهنى ثيانى كومهالًايهتى" يهكهميان وهك

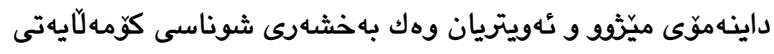

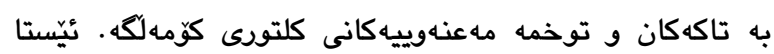

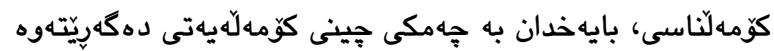
بو بايهخدان به لايهنى دووه م، واته رههدنده كوّمهالّايهتييهكهى جين

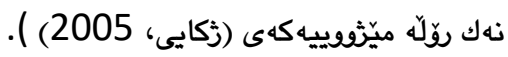

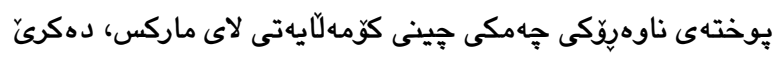
له جهند خالَهى لاى خوارهوه كورت بكرينهاوه:

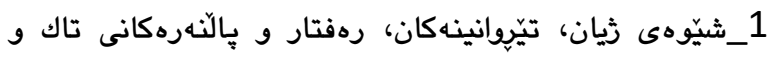
مهلومهارجى ماددى، زيانى _تاك_دياريدهكهن •

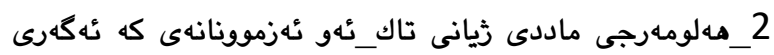

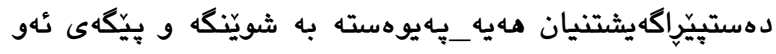
تاكه له نيّو سستمى بهرمهمهيّناندا.

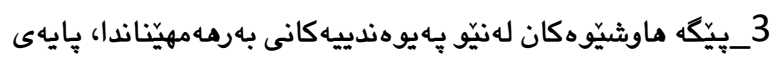

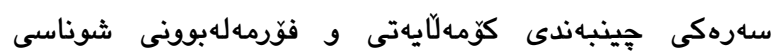
كوّمهالًايهتييه.

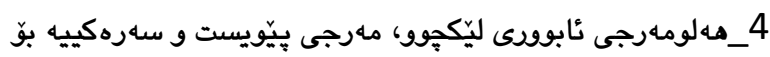
دروستبوونى جين.
ههموويان ريّكه كهليَكن، كه بههويانهوه دهكريّت شيّوازى ثيانى جينهان ده ستنيشان بكريّن و بهوَيهوه لهيهك جيابكرينّهوه.

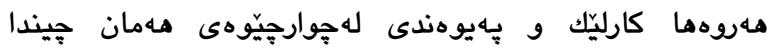
فاكتهريكى ريّكخراوه كه بهنزيكهيى هـمان شيّوازى ريان دينيّته تئاراوه، ئهويش له ميانهى دهستكهوتنى ههمان بريى داهات. مهر ئهمه وا دهكات-تاك- خوّى لهوانى ديكه جيابكاتهوه، كه

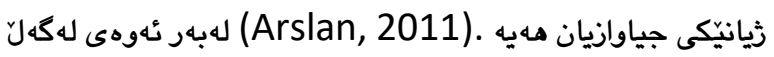
ويّكجِووهكانى خَّيدا زياتر ئاسووده دهبيّت و دهزانيّت -وهك جهّن

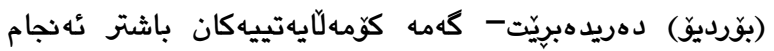

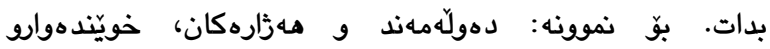

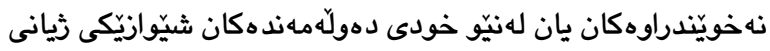

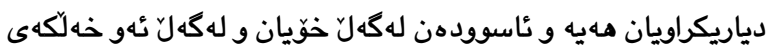
وهك خوّيانن. له كاتيّكدا (بهشيّوهيهكى ريّزَهي) نئهان ئاسووده

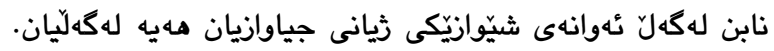

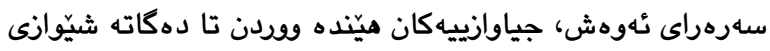
جياواز له شـمهك يِوّشين، جِوّنيهتى و نئهتهيّتى نان خواردن و شيّوازى دانيشتن و جِالاكييهكانى ديكه، تهنانهت شيّوازى قسهكردن و زمانى ئاخافتنيشيان جياوازه وهك جِوّن(انغليز و هيوسون،

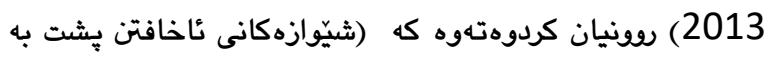

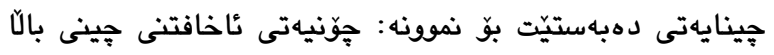
بهمايهكى نِد زياترى ههيه له شيّوازى ناخافتنى جِينى ناوهند و جينى خوارو له كومهلكا روّذئاواييهكان. بهشيّوهيهكى ديكه

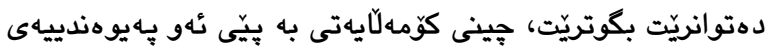

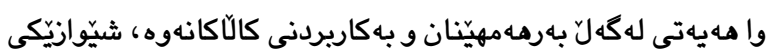
ثيانى تايبهتى دهبيّت. كهواته هـر جينيّكى كوَمهلَّايهتى شيّوازيّكى ثيانى تايبهتى هـيه و بههويهوه دهيهويّت خوّى لهوانى ديكه

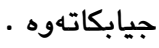

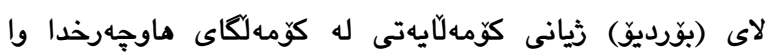
سهرنجى ليّدهدريّت، كه مهيدانيّكى فره رههدنده و كرووي و بكهره

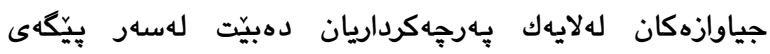
(Swartz, كوّمهلايهتى، له لايهكى تريشهوه لهسهر شيّوازى ثيان (2012، كه بيّكومان مهريهكهيان ماوشانى يهكترن و تيّكيرِّاون. تُهو يوّليّنبهنديهك بوّ جينه جياوازهكان دهكات كه كيّبهركيّى يهكتر دهكهن بوّ دهستكهوتنى دهسهلات -سياسى يان كوّمهلايهتى يان

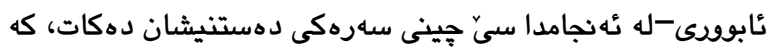

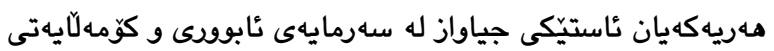

كولتووريان مهيه، ئهوانيش بهمشيّوهيهى لاعى خوارهوهن: (2)

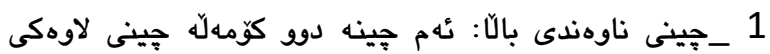
لهخوّدهرِيت: 
تاكهكان بزوتنهوه كوّمهلايهتييه نويّكان، نموونهيهكن لهو

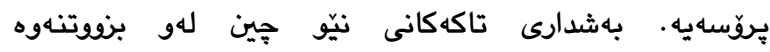

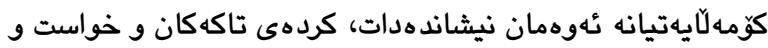
ֶِهيوهنديهكانيان له زياندا جياواز له رابردوق لهسهر بنهماى براردهى

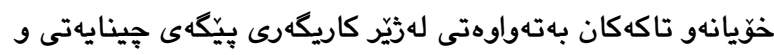

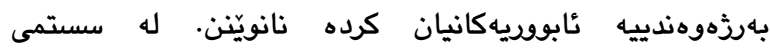

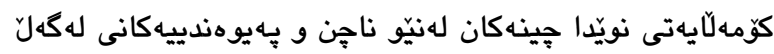

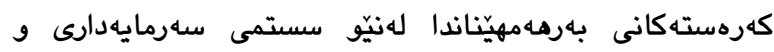

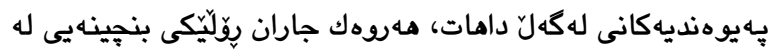

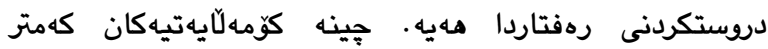
له رابردوو بنهمایى دروستبوونى شوناسى كوّمهلآيهتين. بهواتايهكى ديكه، له مهلوماهرجى نويّدا كه مهنديّك ناويان ناوه يِوّست موّديّرنه، تايبهتمهندييه بابهتييهكانى جينهكان بهمهمان شيّوهى رابردوو

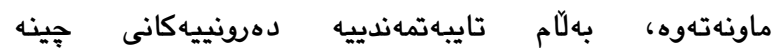
كوّمه لَّيهتييهكان بهشيّوهيهكى كثتى كُوراون. بوّ ناسينى تاكهكان، نارهزوهوكانيان، داواكارييهكانيان و جوّنيهتى رهفتاركردنيان و

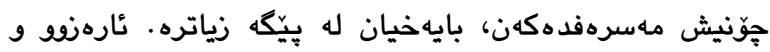
شيّوازى بهكاربردن لهيِيش مهموو شتيّكدا شوناسى تاكهان دياريدهكهن. بوّيه جههمى شيّوازى زيان دهروازهيهكى تازهمان بو به

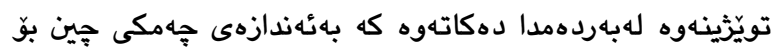
زانسته كوّمهلّايهتييهكان بايهخى تيوّرى ههيه (فاجلى، 2003، 70

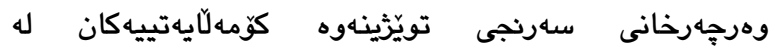
جالاكييهكانى بهرهه مهيّنانهوه بو جالاكييهكانى بهكاربردن، بهواتاى لهجيّانانى كريمانهيهكى بنيادى پِهيوهست به بنهمایى جياوازييه

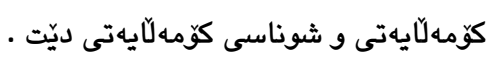

ئهو كوّرإنى ئاراستهيه دهكريّت له سيّ بواردا ببينينهوه" يهكهميان

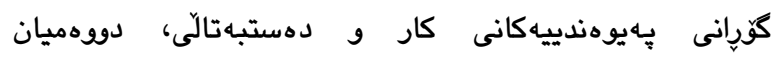
دروستبوونى جينى ناوهند و سيّيهميان كهشه و پِهرهسهندنى كلتورى بهكاربردن. شيّوازهكانى ثيان به كثتى به بناغهى بنيادى كوّمهلاّيهتى بهكاربردن دادهنريّن و له برى بنيادى كوّمهلّايهتى بهرهـمهيّنان كه لهشيّوه كلاسيكيهكيدا بنجينهى يِيّكهاتهى جينايهتييه، جه خت لهسهر سستمى يهيوهست به يهيوهندييهكانى بهكاربردنى دهكريتهوه. بهكاربردن، به بهراودد به بيّكهاته

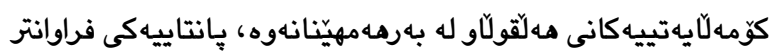

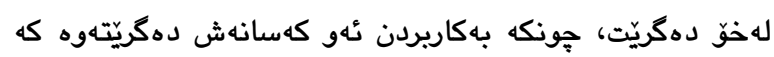

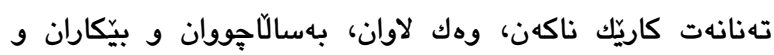

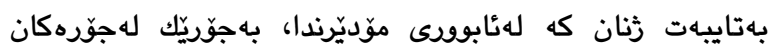

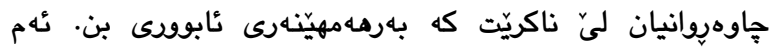

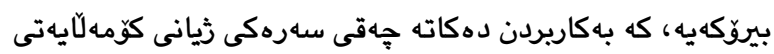
مهروها بووهته بههاى كلتورى (يان دهبيّته بههاى كلتورى)،

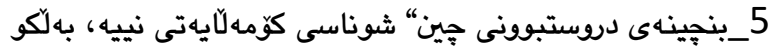
تهنها لهالّتى كهيشتنى به هوشيارى جينايهتى و رِيَكخراوى سياسى و ململانى لهكهل جِينه كانى ديكهدا، دهبيّت به شوناسى

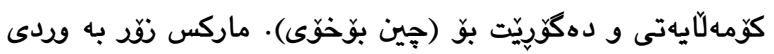

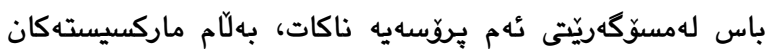
جياوازى بوّجونيان لهبارهيهوه ههيه، كه ماركسيزمى سوّثيهتى

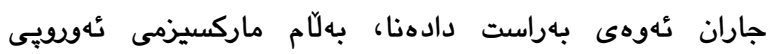

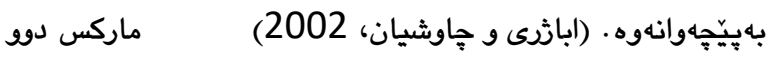
بوّجوونى جياوازى بوّ جֶهمكى جֶين خستهروف، يهكهميان وهك

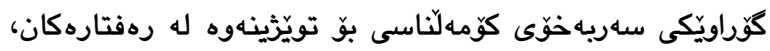

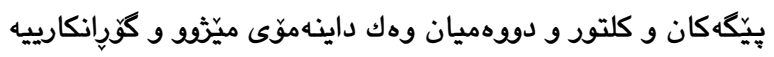

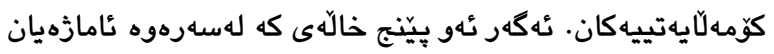

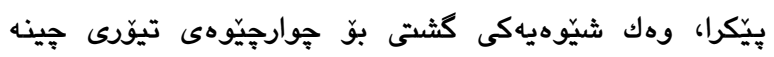
كوّمهلايهتييهكانى ماركس تهماشابكريّت، ئهو كاته تهنها خالّى يِينجهم" جينى وهك هوَكارى ميّزثويى و سياسى ناساندووه.

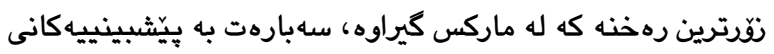
ئهوهوهيه" بهلاّم ئهو رهمهنده له تيوّرى جينايهتى ئهودا، هيع لهبايهخى شيكارى و دوّزينهوهكانى ئهو كهمناكه نهوه ـ ئهو خالَّانهى

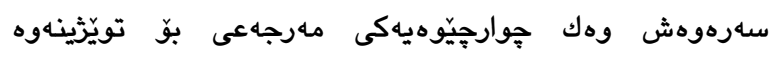

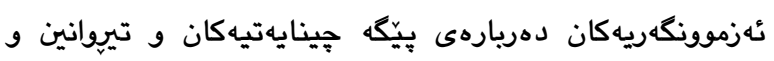

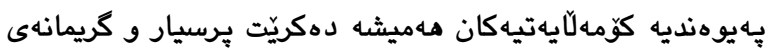

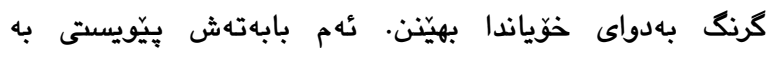
تويّزينهوهى ئهزموونكهرايى بهرفراوان هـيه دهريارهى جينى

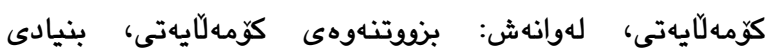

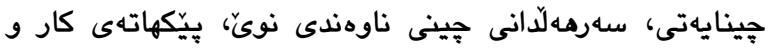

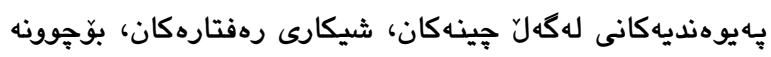

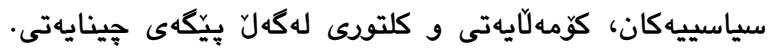

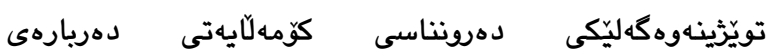
جينهكان"بابهت و دهروازهى كرنكن، كه له تيوّرى هينه

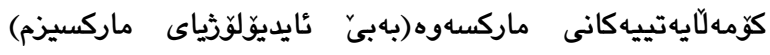
سهرجاوهيان كرتووه. بايهخ و ماناى هدريهكيّك لهو تويَّرينهوانه،

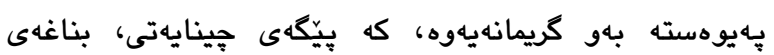

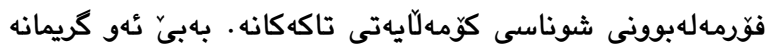
بنياديه، تيوريزهكردن و تويّزينهوهى نئزمونكهرايى دهربارهى جينى كوّمهلّايهتى، لايهنى ئهقلَّنى لهدهست دهدات. بِّيه كاريّكى سروشتيه كه به كومان و دردوّنكييهوه بوّ بايهخ و قورسايى نئهو

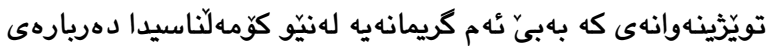
جينه كان كراون، بريوانين .

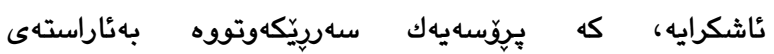
كهمكردنهوهى روّلَى بِيّكه جِينايهتييه كان له دروستكردنى شوناسى 
-تويَّْهرانى كوَمهلّايهتى لهم سهردهمهدا، (بنهمایى شوناسى تاكيان

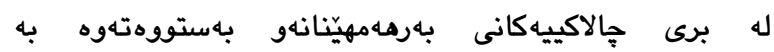
جالاكييه كانى بهكاربردنهوه، لهبهر ئهوه ئهوهى تا تئيستا كوتراوه،

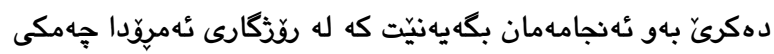
شيّوازى ثيان جيَّرهوهى جهمكى جين نييه، بهالكو ماوثانى ئهو

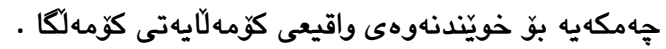

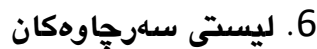

اباثرى، يوسف و جاوشيان، حسن(2002)، از كبقه اجتماعى تا سبك زندكى:

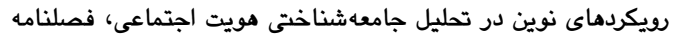

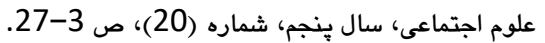

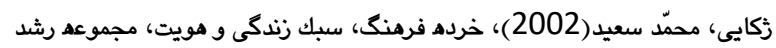

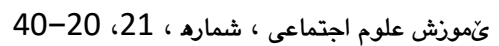

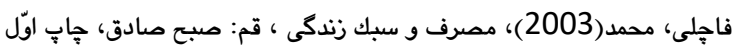

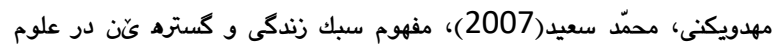

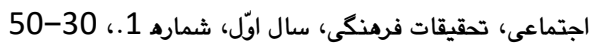

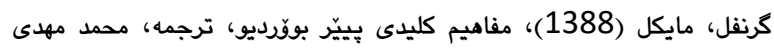
لبيبى، تهران: شركت نشر نقد افكار.

انغليز، ديفد و هيوسون، جون (2013)مدخل الى سوسيولوجيا القِقافه، ترجمه : لما نصير، بيروت: المركز العربى للابحاب و دراسات السياسات.

Arslan, Z.E.R.R.İ.N., 2011. Urban Middle Class, Lifestyle and Taste in Keçiören and Çankaya, Ankara: Distinction through Home Furniture and, Furnishing and Decoration. Basılmamış doktora tezi). Orta Doğu Teknik Üniversitesi/Sosyal Bilimler Enstitüsü, Ankara.

Bourdieu, P. (1984). Distinction: A social critique of the judgement of taste. Harvard university press.

Bourdieu, P. (1998). Practical reason: On the theory of action. Stanford University Press.

Crompton, R., 1996. Consumption and class analysis. The Sociological Review, 44(S1), pp.113-132.

Galobardes, B., Costanza, M.C., Bernstein, M.S., Delhumeau, C. and Morabia, A., 2003. Trends in risk factors for lifestyle-related diseases by socioeconomic position in Geneva, Switzerland, 1993-2000: health inequalities persist. American journal of public health, 93(8), pp.1302-1309.

Gibbins, J.R. and Reimer, B., 1999. The politics of postmodernity: An introduction to contemporary politics and culture. Sage.

Giddens, A. (1991). Modernity and self-identity: Self and society in the late modern age. Stanford university press.

Giddens, A., 1991. Modernity and self-identity: Self and society in the late modern age. Stanford university press.

Holt, D.B. and Searls, K., 1994. The impact of modernity on consumption: Simmel's Philosophy of Money. ACR North American Advances

Jensen, M., 2009. Lifestyle: suggesting mechanisms and a definition from a cognitive science

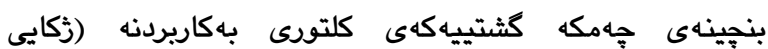

. (2005،

\section{5. ئهنجام}

-جهمكى شيّوازى زيان، نهك وهك بواريّك بِّ تويَرِينهوه له جهمكى

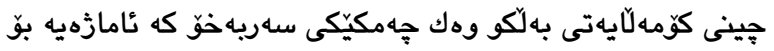
يوانينيّكى نويَ بوّ واقيعى كوّمهلّايهتى و دياردهكانى ديكهى

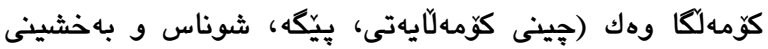
ناسنامهى كوّمهلآيهتى به گرويه كوّمهلَّايهتيهكان) ماتووهته نيّو زانسته كوّمهالّايهتييهكانهوه.

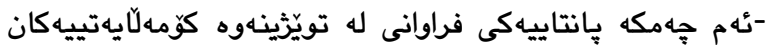
داكيركردووه و سوودى له بهكاربردن وهركرتوه بوّ خو جياكردنهوهى كروبيه كوّمهلآيهتييهكان و دهستخستنى شوناسى

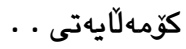

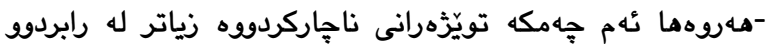
بايهخ به كوولتوود بدهن و هـلّوه ستهى زياترى لهسهر بكهن . -تيّكهيشتنى نوى و تويَزينهاوه لهبارهى شيّوازى ثيانهوه وايكردوه

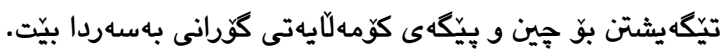
-جهمكى شيّوازى ريان بهبهراود به رابردوو، زانسته كوّمهلّايهتييهكانى به دهرهاويشتهكانى خوّيهوه نِّ سهرقالكردوه. ببوه به بابهتيّك كه جكه له كومهلّاسى زانستهكانى وهك

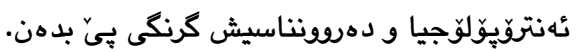
-شروّثهى نوىَ بوّ شيّوازى زيان، خوينّدنهوهيهكى واقيعييانه تره

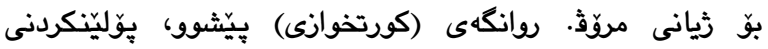
تاكهكانى خستبووه زيّر كوتارى وهك: رهكهز، نهزاد، نهتهوه و و

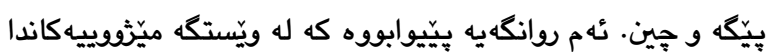
و زهمينه كوّمهلاّيهتييه جوَراوجوَرهكاندا، شيّوه و بِيّكهاتهى لهم

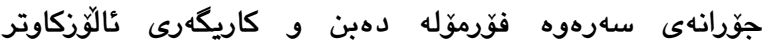
دهخولقيّنن. جيا لهمهاش، ئه يِيّكهاتانهى سهرهوه له ريانى رِّرانهدا شيّوه رهفتارى تايبهت لهخوّياندا نيشان دهدهن، ئهمهاش دهبيّته هوّاريّك كه نهتوانريّت ههنديّك له دياردهكان به تهواوى و لهسهر تايبه تمهندى تاكايهتى تاك و كرويـكان، خويّندنهوهيان بوّ بكريّت .

- ئهوهى وايكردووه جهمكى شيّوانى ثيان له موّديّله تيوّريه

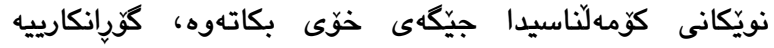
بنيادييهكانى وهك بهبرهويوونى (بهكاربردنكهرايى) و بايهخى سهربه خوّ كاركردنى تاك و ئازادى تاكهكانه له برَاردهانيان .

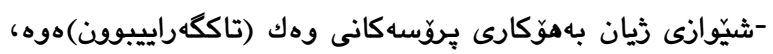

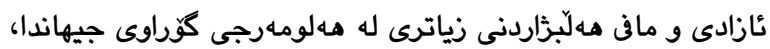
بوّ تاكهكان فهرامه م دهكات. 
Trigg, A.B., 2001. Veblen, Bourdieu, and conspicuous consumption. Journal of economic issues, 35(1), pp.99-115.

Veblen, T.(2007). Theory of the Leisure Class (Oxford world's classics). Transaction Publishers.

Wacquant, L., 1991. Making class: the middle class (es) in social theory and social structure. Bringing class back in: Contemporary and historical perspectives, pp.39-64.

Weber, M., 1978. Economy and society: An outline of interpretive sociology (Vol. 1). Univ of California Press.

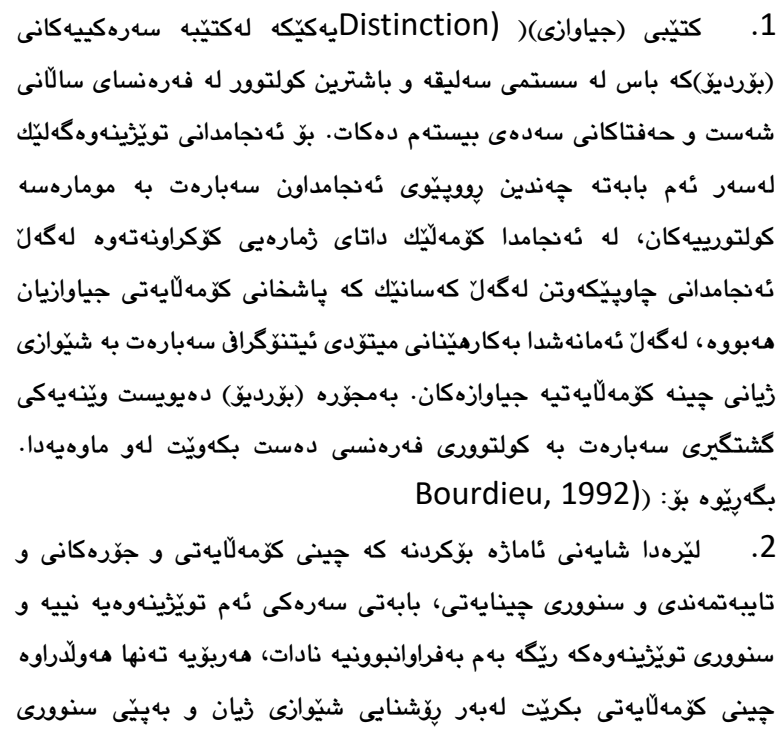

\section{نمط الحياة و نماذجه النظرية (دراسة نظرية)}

perspective. Environment, development and sustainability, 11(1), pp.215-228.

Mohammadpur, A. and Mahmoodi, K. (2016). Lifestyle and identity in contemporary Iranian Kurdistan (a grounded study of Marivan City). Quality \& Quantity, 50(5), pp.1907-1928.

Pisman, A., Allaert, G. and Lombaerde, P., 2011. Urban and suburban lifestyles and residential preferences in a highly urbanized society. Experiences from a case study in Ghent (Flanders, Belgium). Belgeo. Revue belge de géographie, (1-2), pp.89-104.

Rössel, J., 2007. Conditions for the explanatory power of life styles. European Sociological Review, 24(2), pp.231-241.

Savage, M., Devine, F., Cunningham, N., Taylor, M., Li, Y., Hjellbrekke, J., Le Roux, B., Friedman, S. and Miles, A., 2013. A new model of social class? Findings from the BBCs Great British Class Survey experiment. Sociology, 47(2), pp.219-250.

Simmel, G., 1957. Fashion. American journal of sociology, 62(6), pp.541-558.

Simmel, G., 2012. The metropolis and mental life. In The urban sociology reader (pp. 37-45). Routledge.

Swartz, D., 2012. Culture and power: The sociology of Pierre Bourdieu. University of Chicago Press.

Tolonen, T., 2013. Youth cultures, lifestyles and social class in Finnish contexts. Young, 21(1), pp.5575.

Tolonen, T., 2013. Youth cultures, lifestyles and social class in Finnish contexts. Young, 21(1), pp.5575.

Tomlinson, M., 2003. Lifestyle and social class. European Sociological Review, 19(1), pp.97111. 


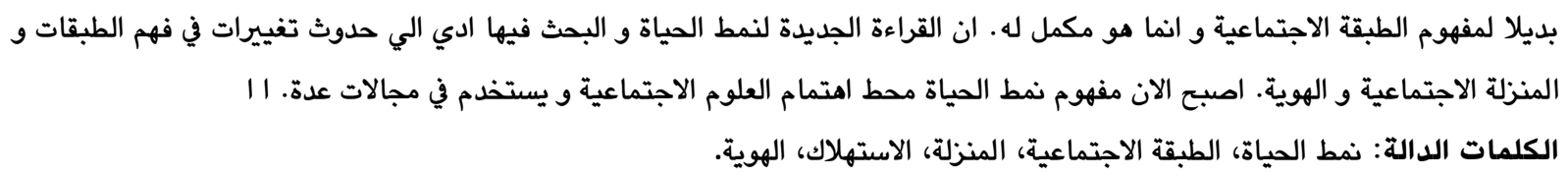

\title{
Lifestyle and its Theoretical Paradigm (A theoretical Study)
}

\begin{abstract}
:
The main issue of this research is those theoretical models which are explained by sociological theorogists for understanding and the how to use of lifestyle consept in a scientific aspect. A big part of researchers in the last two decades and from the nineties because of the researches they have seen that lifestyle concept has taken the place of social class concept.their main proof for this matter is that (social classes) has less analytical ablity than lifestyle of individuals for behavior, value and prespectives. This does not mean the erase of social class concept, while it only questions the analytical ablity of social classes, because there is some kind of similarity between the individuals in the same social class, this way it would not be possible to get a true social picture. Therefore nowadays the result of the varied researches about lifestyle have been devided into two groups, one group have included that lifestyle concept can be used instead of social class concept, but the other group concluded that lifestyle concept is related to social class cocept and they can be used together for a better consumption for reading social reality. About the importance of this research, we can say that the present time is the time of various types of changes, time of a new form of life and changing production to consumtion, therefore we need new concepts continuously for reading society that should be reflections to those changes and bring new topics for researching in social sciences. The aim of this research is, how the socologists used this concept for reading behavior, the how to of social reality changes, then analyzing lifestyle concept in the frame of those theory models that are based on lifestyle. However, about the used concept in this research, (analitical theory is used). At the conclusion, the researcher has come to some results including: lifestyle concept, not as a field for researching the social class concept, but as an independent concept which is a sin of a new prespective on the social reality and the other phenomena like (Social classes, statuses, identity and giving social ID to the social groups) have come to into the social sciences. This concept has taken a big space in the social researches and has benefited the prosseces of separatingthe social groups and gaining social identity. This concept has made new understanding about the changes that social classes and status are going through. Lifestyle concept compared to past, it has made the social sciences busy with it.
\end{abstract}

Keywords: Lifestyle, Social Class, Social Status, Consumtion, Social Identity. 